\title{
Relationships between trans-10 shift indicators and milk fat traits in dairy ewes: insights into milk fat depression
}

P. G. Toral ${ }^{\mathrm{a} *}$, R. Gervais ${ }^{\mathrm{b}}$, G. Hervás $^{\mathrm{a}}$, M.-P. Létourneau-Montminy ${ }^{\mathrm{b}}$, P. Frutos ${ }^{\mathrm{a}}$

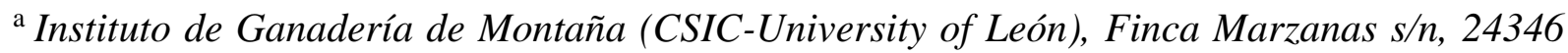

Grulleros, León, Spain

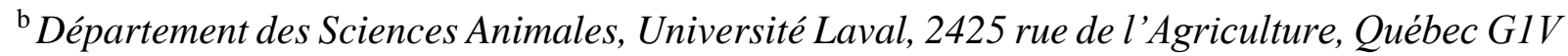
OA6, Canada

${ }^{*}$ Corresponding author. E-mail address: pablo.toral@csic.es (P. G. Toral)

\section{ABSTRACT}

The causative relationship between ruminal biohydrogenation alterations known as the trans10 shift and marine lipid-induced milk fat depression (MFD) has been questioned in dairy ewes, but the large intra- and inter-experiment differences in the levels of trans-10 shift indicators precludes firm conclusions. This meta-analysis was conducted to quantify the relationships between trans-10 shift milk indicators [i.e., trans-10,cis-12 conjugated linoleic acid (CLA), trans-10 18:1 or trans-10:trans-11 18:1 ratio] and lactation performance, mainly milk fat traits, in Assaf dairy ewes. A database comprising of 17 experiments including 50 dietary treatments was compiled. The diets were grouped into 2 dietary conditions: (1) non-MFD condition, which included 14 diets supplemented with plant oils and tannins that modified the milk fatty acid profile without lowering milk fat concentration and yield, and 12 respective control diets, and (2) MFD condition, which included 15 diets supplemented with marine lipids that induced the low fat-milk syndrome, and 9 respective control diets. The overall levels of milk trans-10 shift indicators did not differ between dietary conditions, but significant increments were found in 
the supplemented diets relative to their respective controls. A similar linear and negative (slope: $-7.28 \pm 2.816$ ) relationship between milk fat concentration and trans-10,cis-12 CLA was found in both dietary conditions. However, the quadratic negative response of milk fat content to trans-10 18:1 concentration was greater in MFD than in non-MFD condition. In the two dietary conditions, the relationship between milk trans-10,cis-12 CLA or trans-10 18:1 and de novo fatty acid concentration in milk was negative, whereas the relationship with preformed fatty acid proportion was positive. The magnitude of changes in both milk fatty acid groups in response to changes in these trans-10 shift indicators were greater in non-MFD compared with MFD condition. Milk fat yield and trans-10 shift indicators were only negatively related in ewes that were fed marine lipid supplements, because reductions in de novo fatty acid yield with increased shift indicator levels were not counteracted by concomitant increments in preformed fatty acid secretion. The best-fit (lower root mean squared error, higher $R^{2}$ and no prediction biases) equations of milk fat or major milk fatty acid groups, as concentration or yield, were based on milk trans-10 18:1 concentration. In conclusion, different responses between the two conditions to similar shift indicator levels support that the trans-10 shift would not be a major factor explaining the diet-induced low-fat milk syndrome in dairy ewes.

Key words: biohydrogenation pathway, fish oil, low-fat milk syndrome, mammary lipogenesis, trans-10,cis-12 CLA

Abbreviations: ADF, acid detergent fibre; aNDF, neutral detergent fibre assayed with a heat stable amylase; CLA, conjugated linoleic acid; D, dietary condition; DM, dry matter; FA, fatty acid; FPCM, fat and protein corrected milk yield; MFD, milk fat depression; RMSE, root mean squared error; $R^{2}$, coefficient of determination; $\mathrm{SD}$, standard deviation; $\mathrm{SED}$, standard error of the difference. 


\section{Introduction}

Diet-induced milk fat depression (MFD) is defined as a decrease in milk fat content and yield with no change in the yield of milk and other milk components (Bauman and Griinari, 2001), although it may be associated with occasional variations in milk yield in both ewes and cows (Keady et al., 2000; Kairenius et al., 2015; Toral et al., 2017). This inhibition of milk fat synthesis is induced by certain feeding conditions that alter ruminal lipid metabolism (Bauman and Griinari, 2001; Palmquist and Jenkins, 2017). In this regard, a causative relationship between perturbations in ruminal biohydrogenation pathways known as the trans-10 shift and MFD has been demonstrated in dairy cows fed high-starch rations and plant oil supplements (Bauman and Griinari, 2001; Vazirigohar et al., 2014; Dewanckele et al., 2019). This shift is characterized by increases in the ruminal accumulation of the antilipogenic trans-10,cis-12 conjugated linoleic acid (CLA) and of trans-10 18:1, which are often more apparent and can lead to trans-10:trans-11 18:1 ratios above 1 (Loor et al., 2005b; Boeckaert et al., 2008; Conte et al., 2018). Small ruminants are not prone to this type of diet-induced MFD (Mele et al., 2006; Fougère et al., 2018; Parente et al., 2018). However, indications of a trans-10 shift have been found in the milk of ewes and goats fed starch-rich diets and plant oils, such as modest increases of trans-10,cis-12 CLA concentrations and occasional inversions of the trans-10:trans-11 18:1 ratio (Gómez-Cortés et al., 2008b; Hervás et al., 2008; Bernard et al., 2012).

On the other hand, another type of diet-induced MFD has consistently been reported both in cattle and small ruminants receiving marine lipid supplements rich in n-3 polyunsaturated fatty acids (FA; Harvatine et al., 2009; Kliem and Shingfield, 2016; Bernard et al., 2017), a nutritional strategy aimed at manipulating milk composition to enhance desirable FA. Contrary to expectation, MFD due to marine lipids is often associated with little or no change in trans10,cis-12 CLA in the three species (Vahmani et al., 2013; Carreño et al., 2016; Fougère et al., 2018). In some cases, proportions of trans-10 18:1 are not significantly increased either (Cruz- 
Hernandez et al., 2007; Gama et al., 2008; Toral et al., 2017).

Due to these findings, the relevance of the trans-10 shift to marine lipid-induced MFD has been questioned, but the large intra- and inter-experiment differences in the concentration of trans-10-containing FA precludes firm conclusions, particularly in lactating sheep (Moate et al., 2007; Frutos et al., 2017; Toral et al., 2017). Aggregation of observations from lactation traits and associated levels of trans-10 shift indicators (e.g., milk concentrations of trans-10,cis12 CLA and trans-10 18:1, and trans-10:trans-11 18:1 ratio) from independent experiments in the ovine may then lead to a better understanding of their potential inter-relationships in this species.

The objective of this meta-analysis was to quantify the relationships between trans-10 shift milk indicators and lactation performance, mainly milk fat traits (e.g., concentration and yield of milk fat and major milk FA groups), to provide new insights into MFD in highly specialized dairy ewes. Our initial hypothesis was that the trans-10 shift may be related to milk fat traits, but would not be a major causative factor for this syndrome in the ovine.

\section{Material and methods}

\subsection{Database preparation}

A database comprising information from 17 experiments, examining supplementation of plant oils, tannins or marine lipids using 50 dietary treatments in lactating dairy ewes, was compiled (see Table 1). All the experiments were performed at the Instituto de Ganadería de Montaña (León, Spain) between 2005 and 2017, using dairy Assaf ewes [on average ( \pm SD), body weight $=77.8 \pm 7.81 \mathrm{~kg}$, parity $=2.5 \pm 0.35$; days in milk $=63 \pm 7.8]$ under similar management conditions. Each year, sheep were mated at the end of the summer and, after lambing in January-February, the experiments were carried out between March and June. Parallel-group studies were conducted, except in Toral et al. (2016), which followed a Latin 
square design. Diets were based on alfalfa hay (as sole forage source with different proportion) and concentrates and offered ad libitum (to ensure at least $15 \%$ orts daily) as a total mixed ration. Supplements replaced other dietary ingredients on a proportionate basis. Clean drinking water was always available and ewes were milked in a dedicated $1 \times 10$-stall milking parlor (DeLaval, Madrid, Spain).

The 50 dietary treatments were grouped into two dietary conditions according to their effects on mammary lipogenesis: (1) non-MFD condition, which included 14 diets supplemented with plant oils (rich in cis-9 18:1, 18:2n-6 or 18:3n-3) or tannins (non-MFD treatment) and respective 12 control diets (non-MFD control); and (2) MFD condition, which included 15 diets supplemented with marine lipids (alone or in combination with plant oils; MFD treatment) and 9 respective control diets (MFD control; Table 1). The non-MFD condition modified the milk FA profile without causing a significant decrease in milk fat concentration and yield, whereas the MFD condition induced the low-fat milk syndrome (Table 2).

For the sake of homogeneity of the database, observations entered in it corresponded exclusively to lot means, because animals were arranged in lots in some experiments and individual data were not available for all parameters. In trials where animals were individually penned (i.e., Carreño et al., 2015; Castro-Carrera et al., 2015; Frutos et al., 2017; Toral et al., 2011, 2015, 2017, 2018), arithmetic means were calculated for the dietary treatment. Supplements were fed for a minimum period of 3 (plant oils) or 4 (marine lipids and tannins) weeks. If repeated measures were available, arithmetic means were determined to obtain only one final observation per lot of ewes. To ensure steady-state responses, only the results obtained after 3 or more weeks of adaptation to the diets were considered. Therefore, the database included 17 experiments, 50 diets, and a total of 92 lot observations (lot means; Table 1).

Chemical composition of diets included in the database was analysed using standard methods (e.g., Frutos et al., 2017), except for some missing starch concentrations that were 
estimated according to INRA (2007). Data of trans-10 shift milk indicators (i.e., milk concentrations of trans-10,cis-12 CLA and trans-10 18:1, and the trans-10:trans-11 18:1 ratio) were obtained using similar FA methylation techniques and chromatographic equipment and conditions (e.g., Gómez-Cortés et al., 2011b; Frutos et al., 2017). Lactation performance traits included milk yield, fat and protein corrected milk yield (FPCM), and concentration and yield of milk fat and major FA groups according to their origin (i.e., mammary de novo synthesis, uptake from plasma lipids or both). Because different patterns of de novo synthesized and preformed FA during diet-induced MFD have been suggested (e.g., Bauman and Griinari, 2001;

Gervais et al., 2009; Baldin et al., 2013), the first group was represented by the sum of 6:0, 8:0, 10:0, 12:0, 14:0, cis-9 10:1, cis-9 12:1 and cis-9 14:1. Preformed FA were represented by all milk FA with 18 or more carbon atoms, which come exclusively from mammary uptake of plasma lipids. The sum of 16:0 and 16:1 isomers, derived from both sources, represented the third group, whereas other FA (e.g., odd- and branched-chain FA) were excluded from the analysis. The yields of these major FA groups were estimated from milk total FA secretion data, assuming a mean proportion of $933 \mathrm{~g} / \mathrm{kg}$ of total FA in milk fat (Glasser et al., 2007).

\subsection{Statistical analysis}

Diet composition, lactation performance, and trans-10 shift milk indicators data were analyzed by one-way ANOVA, using the MIXED procedure of the SAS software package (version 9.4; SAS Institute Inc., Cary, NC, USA). The statistical model included the fixed effect of the experimental treatment (non-MFD control, non-MFD treatment, MFD control, and MFD treatment) and the random effect of experiment. When the effect of the experimental treatment was significant, pre-planned orthogonal contrasts were used to test the significance of the effects of supplementation (control vs. treatment) within non-MFD or MFD conditions, as well as to examine overall differences between non-MFD and MFD dietary conditions. Least square 
means are reported throughout.

Relationships between lactation performance traits and milk trans-10 shift indicators were examined using the MIXED procedure of SAS. The observations in the database were the lot means, as detailed in the previous section. Outliers, defined as data for which the absolute value of conditional studentized residuals was $\geq 3.0$, were not found in the database. The normal distribution of residues and the homogeneity of the variance (or homoscedasticity) were then confirmed. For each lactation performance trait, the prediction model included the fixed effects of the dietary conditions (non-MFD vs. MFD), the linear and quadratic effects of the particular trans-10 shift indicator (i.e., trans-10,cis-12 CLA, trans-10 18:1, or the trans-10:trans-11 18:1 ratio), and the interactions between dietary condition and the corresponding shift indicator. The experiment was also included in the model as the random effect. Values reported in Tables 3 to 6 correspond to the least square means ( \pm standard error) of intercepts and linear and/or quadratic regression coefficients. The effect of the dietary condition was automatically included in the prediction model and, therefore, the intercepts were always calculated separately for nonMFD and MFD, providing information of the different dispersion of data in each dietary condition. However, the linear and quadratic effects of the particular trans-10 shift indicator, and the interactions between each of them and the effect of the dietary condition were only kept in the final model when significant (i.e., when $\mathrm{P}<0.05$ ). In line with this, linear or quadratic regression coefficients were calculated separately for non-MFD and MFD conditions when the interactions were significant. On the contrary, when the interactions were not significant, the regression coefficients were calculated for non-MFD and MFD together, which resulted in a single mean ( \pm standard error) for the two dietary conditions.

The REG procedure of SAS was used to determine fit statistics of each prediction model, specifically the root mean squared error (RMSE) and the coefficient of determination $\left(R^{2}\right)$ for the linear relationships between studentized residuals of observed and predicted values. The 
REG procedure was also used to assess prediction bias by regressing residuals against predicted values (St-Pierre, 2003) to confirm that neither the slopes nor the intercepts were significantly different from zero. For each model, predicted values were centered around their mean value and used as an independent variable.

The CORR procedure of SAS was used to generate Pearson correlation coefficients $(r)$ among lactation performance traits and trans-10 shift indicators.

\section{Results}

The diets supplied to ewes contained on average $( \pm$ SD) $377( \pm 140.0) \mathrm{g} / \mathrm{kg}$ of forage, with no variation $(\mathrm{P}>0.10)$ between dietary conditions (Table 2$)$. Differences were not detected $(\mathrm{P}>0.10)$ in aNDF, ADF and total starch, and FA concentrations between dietary conditions, with means of $265( \pm 67.5), 170( \pm 72.0), 192( \pm 55.7)$ and $39( \pm 29.3) \mathrm{g} / \mathrm{kg}$ of diet DM, respectively. The contribution of corn and barley grains to dietary starch was similar $(\mathrm{P}>0.10)$ in both dietary conditions (Table 2). On the contrary, crude protein concentration tended $(\mathrm{P}<0.10)$ to be slightly lower in non-MFD compared with MFD. Very long-chain $\mathrm{n}-3$ polyunsaturated FA were only detected in supplemented MFD diets, which also showed greater proportions of 14:0, 16:0, cis-9 16:1, 18:0 and cis-11 18:1 than the control MFD. In non-MFD, supplemented diets had greater $(\mathrm{P}<0.001)$ proportions of 16:0, cis-9 18:1 and 18:2n-6 compared to the control MFD.

Overall levels of milk trans-10 shift indicators did not differ $(\mathrm{P}>0.10)$ between dietary conditions, but increments $(\mathrm{P}<0.01)$ were found in the supplemented diets relative to their respective controls (Table 2). In non-MFD condition, milk yield increased $(\mathrm{P}<0.01)$, milk fat yield tended to increase $(\mathrm{P}<0.10)$, milk fat content was not changed $(\mathrm{P}>0.10)$, milk de novo and C16 FA concentrations and yields decreased $(\mathrm{P}<0.05)$, and milk preformed FA increased $(\mathrm{P}<0.001)$. In MFD conditions, the yields of milk fat and all milk FA groups were $(\mathrm{P}<0.05)$ 
lower in supplemented diets, which also reduced $(\mathrm{P}<0.001)$ milk fat concentration. Concentrations of de novo and C16 FA in milk were greater $(\mathrm{P}<0.05)$ and preformed FA was lower $(\mathrm{P}<0.01)$ in MFD compared with non-MFD conditions.

The $R^{2}$ for the linear relationships between studentized residuals of observed and predicted values ranged between 0.45 and 0.87 (Tables 3, 4 and 5). The $R^{2}$ values for milk fat yield equations were more similar compared with milk fat concentration equations $(0.72-0.80$ and 0.51-0.79, respectively; Tables 3, 4 and 5). The intercepts of the plots of the residual vs. predicted values were not $(\mathrm{P}>0.10)$ different from zero, indicating absence of overall prediction bias for models (data not shown). Slopes of these plots were not $(\mathrm{P}>0.10)$ different from zero either, except for the relationships between trans-10,cis-12 CLA and milk fat concentration $(\mathrm{P}<0.10)$, and between trans-10:trans-11 18:1 ratio and de novo FA concentration $(\mathrm{P}<0.10)$, preformed FA yield $(\mathrm{P}<0.05)$ or $\mathrm{C} 16 \mathrm{FA}(\mathrm{P}<0.10)$. The best-fit (lower RMSE, higher $R^{2}$ and no prediction biases) equations of milk fat or major milk FA groups, as proportion or yield, were based on milk trans-10 18:1 concentration.

Milk yield did not show ( $\mathrm{P}>0.10)$ relationship with milk trans-10,cis-12 CLA, and was not affected $(\mathrm{P}>0.10)$ by the dietary condition either (Table 3). A similar linear and negative (slope: $-7.28 \pm 2.816 ; \mathrm{P}<0.05$ ) relationship was found between milk trans-10,cis-12 CLA and milk fat concentration (Figure 1) was found in both non-MFD and MFD, but a relatively low $R^{2}(0.51)$ and a prediction bias (based on slopes of the residual vs. predicted values) were found. A significant interaction between the effects of dietary condition and trans-10,cis-12 CLA was detected for milk fat yield, with only marginal reductions in non-MFD and a pronounced and quadratic inverse relationship in MFD (Table 3). The concentration of milk trans-10,cis-12 CLA was negatively related (slope: $-48.3 \pm 10.52 ; \mathrm{P}<0.001$ ) to the yield of de novo FA, without any interaction $(\mathrm{P}>0.10)$ with dietary condition, whereas the positive relationship with preformed FA yield was more pronounced in non-MFD compared with MFD (slopes: 
56.0 \pm 11.51 and 31.3 \pm 11.84 , respectively; $\mathrm{P}<0.01$; Table 3 ). However, C16 FA yield was less affected in non-MFD than in MFD (slopes: $-21.2 \pm 7.05$ and $-35.8 \pm 7.89$, respectively; $\mathrm{P}<0.05$ ). Interactions between dietary condition and the linear effect of trans-10,cis-12 CLA were also detected when de novo and preformed FA were expressed as proportion of total FA, and the decrease in the former and the increase in latter were stronger $(\mathrm{P}<0.05)$ in non-MFD (Table 3$)$.

Milk trans-10 18:1 and trans-10:trans-11 18:1 ratio led to different prediction models for milk fat concentration, and the quadratic negative response to trans-10 18:1 concentration in MFD was greater $(\mathrm{P}<0.05)$ than in non-MFD condition (Tables 4 and 5 and Figure 1). Milk trans-10 18:1 showed a linear relationship with milk fat yield in non-MFD (slope: $0.043 \pm 0.0972 ; \mathrm{P}<0.001$ ) and MFD (slope: $-0.576 \pm 0.0865 ; \mathrm{P}<0.001$ ). Milk trans -10 18:1 showed a positive linear $(\mathrm{P}<0.001)$ relationship with preformed FA yield and negative linear $(\mathrm{P}<0.001)$ relationships with de novo and C16 FA yields in non-MFD. When milk fat traits were expressed as a proportion, the reductions in de novo and C16 FA and increases in preformed FA were more pronounced (slopes: $-2.00 \pm 0.223,-1.72 \pm 0.267$ and $4.82 \pm 0.745$, respectively; $\mathrm{P}<0.001$ ) in non-MFD compared with MFD (Table 4 and Figure 2).

The analyses conducted with the ratio of trans-10:trans-11 18:1 suggested a lack of significant relationships between this shift indicator and preformed FA yield, and resulted in the lowest $R^{2}$ for milk fat yield, FPCM and the de novo, preformed and C16 FA concentrations and yields (Table 5), in line with prediction biases described above. For milk fat yield and FPCM, the observed interactions between dietary condition and the linear effect of the trans10:trans-11 18:1 ratio $(\mathrm{P}<0.01$ and $\mathrm{P}<0.05$, respectively) led to similar results to those described for trans-10 18:1.

Milk trans-10,cis-12 CLA showed positive significant correlations $(r=0.465 ; \mathrm{P}<0.001)$ with milk trans-10 18:1, and non-significant ( $r=0.158 ; \mathrm{P}>0.10)$ correlations with trans10:trans-11 18:1 (Supplementary Table S1). Milk yield was correlated to most milk fat traits, 
such as milk fat yield $(r=0.841 ; \mathrm{P}<0.001)$ or $\mathrm{C} 16$ FA concentration $(r=0.766 ; \mathrm{P}<0.001)$. Milk fat yield was also positively correlated to yields of de novo FA $(r=0.867 ; \mathrm{P}<0.001)$ and preformed FA $(r=0.578 ; \mathrm{P}<0.001)$ but not with C16 FA $(r=0.095 ; \mathrm{P}>0.10)$, although a strong positive correlation $(r=0.922 ; \mathrm{P}<0.001)$ was found with milk C16 FA concentration. However, milk fat concentration was not correlated $(\mathrm{P}>0.10)$ to the yields or contents of major FA groups, except for a marginal correlation $(r=0.182 ; \mathrm{P}<0.10)$ with $\mathrm{C} 16$ FA concentration. In general, milk preformed FA content showed negative correlations with other milk fat traits, such as the yields of milk fat $(r=-0.255 ; \mathrm{P}<0.05)$, de novo FA $(r=-0.678 ; \mathrm{P}<0.001)$ and C16 FA $(r=-0.851$; $\mathrm{P}<0.001)$ or the concentrations of de novo $(r=0.954 ; \mathrm{P}<0.001)$ and C16 FA $(r=-0.541 ; \mathrm{P}<0.001)$.

\section{Discussion}

Unravelling the basis of diet-induced MFD has been a major challenge for dairy nutritionists for many years. The discovery of a correlation between mammary lipogenesis and the trans-10 shift in ruminal biohydrogenation represented a breakthrough on the theories proposed to explain the syndrome (Bauman and Griinari, 2001; Palmquist and Jenkins, 2017). This shift provides a robust explanation for detrimental effects of high-concentrate diets and unsaturated plant lipid supplements on milk fat synthesis in cows (Loor et al., 2005b; Saliba et al., 2014; Vazirigohar et al., 2014). However, little is known about the mechanisms resulting in the apparent lack of response of sheep to such milk fat depressing conditions. Furthermore, marine lipids can cause MFD in both sheep and cows without an obvious trans-10 shift (CruzHernandez et al., 2007; Toral et al., 2017; Fougère et al., 2018). Therefore, a meta-analysis examining the relationships between trans-10 shift indicators and milk fat traits in dairy ewes showing or not marine lipid-induced MFD might improve our understanding of the link between rumen lipid metabolism and milk fat synthesis. Our database, representative of intensive dairy production systems and including different types of lipid supplementation, provides a 
particularly suitable scenario in this regard, but caution must be taken before extrapolating results to other breeds or management conditions (e.g., non-specialized or dual-purpose breeds, extensive grazing in semi-arid and harsh lands, etc.; Haenlein, 2007).

Increases in milk trans-10,cis-12 CLA are often not significant in ewes receiving marine lipids (e.g., Toral et al., 2010a, 2017). Therefore, the significant increment in the concentration of this CLA isomer after lipid supplementation in the MFD group may likely derive from the greater statistical power after compilation of measurements from individual studies. Milk fat concentration and trans-10,cis-12 CLA level were inversely related in both MFD and non-MFD (Figure 1). This observation was particularly unexpected in the latter condition, which included diets of different forage:concentrate ratio supplemented with plant oils and extracts. No detrimental effects of these feeding strategies on milk fat synthesis had been detected when each experiment was individually analyzed (e.g., Hervás et al., 2008; Castro-Carrera et al., 2015), but the aggregation of results in the database and the consequent increment in the statistical power seems to have facilitated the detection of significant, though modest, changes (Sauvant et al., 2008; Leduc et al., 2014). Although the literature on this topic suggests that high-concentrate diets and plant lipids do not hamper milk fat synthesis in small ruminants (Mele et al., 2006; Nudda et al., 2015; Tsiplakou et al., 2017), occasional reductions in milk fat concentration have been reported in ewes and does (Zhang et al., 2006; Bernard et al., 2012; Shi et al., 2015). Furthermore, trans-10,cis-12 CLA (the main factor responsible for the associated MFD in cattle; Bauman and Griinari, 2001; Palmquist and Jenkins, 2017) inhibits mammary lipogenesis when sheep and goats receive it from external sources (Lock et al., 2006; Shingfield et al., 2010; Baldin et al., 2013). Our results might support a causative, but limited, relationship between increased trans-10,cis-12 CLA concentrations and decreased milk fat content in high-producing dairy ewes. Yet, the low robustness of the prediction model would call into question this finding. In addition, no inverse relationship between this CLA isomer and 
milk fat yield was found in the non-MFD condition, in contrast to their negative association in cows under similar dietary conditions (Bauman and Griinari, 2001; Shingfield et al., 2010).

Although the reasons for interspecies differences in lipid metabolism are still unclear, both ruminal and mammary components might be involved. First, the presumed greater stability of ruminal biohydrogenation pathways in small ruminants than in cattle may result in less exposure of the mammary gland to antilipogenic FA (Shingfield et al., 2010; Bernard et al., 2017). In this regard, milk trans-10,cis-12 CLA concentration appears to be lower in sheep than in cows receiving similar diets (Gómez-Cortés et al., 2011b; Vazirigohar et al., 2014; Conte et al., 2018), consistent with greater perturbations in ruminal biohydrogenation in the latter species, but direct comparative studies would be required to confirm this hypothesis. Concerning the mammary component, Shingfield et al. (2010) summarized milk fat responses to dietary inclusion of rumen protected CLA products and found a greater sensitivity of mammary lipogenesis to trans-10,cis-12 CLA in cows than in goats, although available information in ewes was too scant for modeling their biological response and establishing interspecies comparisons.

The relationship between milk fat concentration and trans-10 18:1 in the non-MFD condition was similar to that described for trans-10,cis-12 CLA (Figure 1), but the antilipogenic activity of the 18:1 isomer in the bovine is equivocal (Harvatine et al., 2009; Kadegowda et al., 2009; Shingfield et al., 2009) and would prevent from speculating on a cause-and-effect relationship. Nonetheless, its concentration in milk, as well as the trans-10:trans-11 18:1 ratio, has often been considered as a biomarker of altered biohydrogenation pathways that detrimentally affect mammary lipogenesis (Moate et al., 2007; Boeckaert et al., 2008; Harvatine et al., 2009). Using the trans-10:trans-11 18:1 ratio resulted in prediction models for milk fat concentration and yield that were similar to those of trans-10 18:1, but less robust (i.e., associated with higher RMSE and lower $R^{2}$ ), which would downplay its relevance as an 
effective indicator in lactating ewes. A putative explanation might relate with the fact that high trans-10 18:1 concentrations can be accompanied by even higher trans-11 18:1 proportions in ovine milk, in contrast to their clearly inverse relationship in the bovine (Hervás et al., 2008; Shingfield et al., 2010; Saliba et al., 2014).

Our initial hypothesis was that the trans-10 shift may be related to milk fat traits, which was confirmed by results, but would not be a major factor explaining marine-lipid induced MFD in sheep. The second premise would be supported by the divergent responses to similar increments of milk trans-10 shift indicators in MFD and non-MFD conditions (Figures 1 and 2), and may suggest that the origin of this specific condition would lie in less-well studied aspects (Frutos et al., 2017; Toral et al., 2017).

The comparison of non-MFD and MFD diet composition (Table 2) points to marine lipid supplementation as the single reason for the presumed alterations in the ruminal environment in the latter condition. Although the biohydrogenation process and its response to lipid addition are known to be strongly influenced by the basal diet composition, such as the forage:concentrate ratio or the content and type of starch (Mele et al., 2006; Bernard et al., 2012; Pirondini et al., 2015), these parameters did not significantly differ between the two conditions in the database. Other management and environmental conditions were also similar in MFD and non-MFD.

On the contrary, marine lipids supplied certain unsaturated FA that have been suggested as candidate milk fat inhibitors or modulators of the ruminal environment (Harvatine et al., 2009; Kadegowda et al., 2009; Shingfield et al., 2010). For example, cis-9 16:1, cis-11 18:1 and 20:5n-3 exert suppressive effects on lipogenic gene expression and fat synthesis in cell cultures (Kadegowda et al., 2009; Burns et al., 2012). This inhibitory activity might account for the moderate reductions in milk fat concentration after postruminal infusions of fish oil, but would not, in isolation, explain the MFD extent when these lipids are added to the diet (Loor et al., 
2005a; Dallaire et al., 2014). Alterations in the ruminal metabolism other than the trans-10 shift might also be crucial, such as oxo-FA accumulation (Kairenius et al., 2015; Carreño et al., 2016). Further research would also be necessary to understand the actual association between marine lipid-induced MFD and less well-known ruminal BH intermediates (e.g., trans-13containing FA and conjugated 18:3 isomers; Gervais and Chouinard, 2008; Dewanckele et al., 2019; Toral et al., 2019) or ruminal acetate production (Urrutia and Harvatine, 2017; Frutos et al., 2018). Perhaps a combination of all these factors contributes to explain this MFD type, which is most likely multi-etiological.

The low-fat milk syndrome has classically been described as a decrease in milk fat content and yield with no change in the yield of milk and other milk components, a definition that seems particularly adapted to MFD in cows due to high-concentrate diets and plant lipids (Bauman and Griinari, 2001). However, reports on the use of marine lipids suggest that decreases in milk fat concentration may be associated with reductions, no changes, or even increases in milk yield (Keady et al., 2000; Loor et al., 2005a; Kairenius et al., 2015; Toral et al., 2017). This would concur with the inconsistent behavior of milk yield in the present study, with a quadratic relationship with trans-10 18:1 proportion (Figure 2), a linear association with trans-10:trans11 18:1 (Table 4) and no changes with trans-10,cis-12 CLA (Table 2). Fat- and proteincorrected milk yield followed a similar trend than milk fat yield, probably due to the major influence of this component in estimations.

The segregated analysis of milk de novo, preformed and C16 FA secretions provided information about the origin of the alterations in milk fat yield, supporting a different relationship with the trans-10 shift. In this regard, results suggest that the reductions in de novo and C16 FA yield with increasing shift indicator levels were substantial in both non-MFD and MFD, consistent with a strong inhibitory effect of trans-10 intermediates on mammary de novo FA synthesis (Shingfield et al., 2009, 2010; Hussein et al., 2013). However, increments in 
preformed FA yield counteracted the decrease in de novo and C16 FA secretion in animals without MFD (Figure 2). Differences were also evident when major FA groups were expressed as a proportion of total milk FA, in agreement with results in lactating sheep fed high concentrate diets and plant lipid supplements (Mele et al., 2006; Parente et al., 2018). Concerning interspecies variations, the inhibitory action of exogenous trans-10,cis-12 CLA on preformed FA yield in milk seems to be weaker in goats than in cows (Gervais et al., 2009; Shingfield et al., 2010; Baldin et al., 2013). A similar comparative analysis is not available in ewes. Interspecies differences in the compensatory mechanisms for repressed de novo FA synthesis (e.g., improved preformed FA secretion) have not been examined either.

Under marine lipid-induced MFD, however, the decrease in de novo and C16 FA yield could not be counteracted by a greater secretion of preformed FA (Figure 2), inducing a substantial impairment in milk fat yield. This might also explain some apparent inconsistencies in mammary mRNA responses to marine lipid supplements: downregulation of genes responsible for de novo synthesis is very usual (e.g., in ACACA, FASN or ACSS2), but suppression of genes involved in FA uptake is often non-significant (e.g., in $L P L$ and FABP3; Carreño et al., 2016; Frutos et al., 2017; Toral et al., 2017). Results from earlier studies would also recommend re-evaluating the relevance of preformed FA yield in certain MFD conditions, including the comparison of a mild vs. a severe MFD in ewes (Frutos et al., 2017) or abomasal infusions of fish oil in cows (Dallaire et al., 2014).

\section{Conclusions}

This meta-analysis quantifies the relationships between indicators of the trans-10 shift in ruminal biohydrogenation pathways and milk fat traits in dairy ewes and suggests that, contrary to expectation, a modest inverse relationship between milk fat concentration and shift indicators exists in both non-MFD and MFD conditions. However, milk fat yield and trans-10,cis-12 
CLA, trans-10 18:1, or trans-10:trans-11 18:1 seem negatively related only in MFD, because reductions in de novo FA yield with increased shift indicator levels are not counteracted by concomitant increments in preformed FA secretion. The best-fit equations of milk fat or major milk FA groups, as concentration or yield, are based on milk trans-10 18:1 concentration. Different responses between the two conditions to similar shift indicator levels support that the trans-10 shift would not be a major factor explaining the diet-induced low-fat milk syndrome in dairy ewes.

Declarations of interest: none

Acknowledgements: This work was supported by the Spanish Ministry of Economy and Competitiveness (MINECO; AGL2017-87812-R), co-funded by the European Regional Development Fund. P. G. Toral benefited from a Ramón y Cajal research contract from the MINECO (RYC-2015-17230), co-funded by the European Social Fund, and a researcher mobility grant from the University of León.

\section{References}

Baldin, M., Dresch, R., Souza, J., Fernandes, D., Gama, M.A.S., Harvatine, K.J., Oliveira, D.E. 2013. CLA induced milk fat depression reduced dry matter intake and improved energy balance in dairy goats. Small Rumin. Res. 116, 44-50.

Bauman, D.E., Griinari, J.M. 2001. Regulation and nutritional manipulation of milk fat: lowfat milk syndrome. Livest. Prod. Sci. 70, 15-29.

Bernard, L., Leroux, C., Rouel, J., Bonnet, M., Chilliard, Y. 2012. Effect of level and type of starchy concentrate on tissue lipid metabolism, gene expression, and milk fatty acid 
secretion in Alpine goats receiving a diet rich in sunflower oil. Br. J. Nutr. 107, 11471159.

Bernard, L., Toral, P.G., Chilliard, Y. 2017. Comparison of mammary lipid metabolism in dairy cows and goats fed diets supplemented with starch, plant oil, or fish oil. J. Dairy Sci. 100, 9338-9351.

Bichi, E., Hervás, G., Toral, P.G., Loor, J.J., Frutos, P. 2013. Milk fat depression induced by dietary marine algae in dairy ewes: Persistency of milk fatty acid composition and animal performance responses. J. Dairy Sci. 96, 524-532.

Boeckaert, C., Vlaeminck, B., Dijkstra, J., Issa-Zacharia, A., Van Nespen, T., Van Straalen, W., Fievez, V. 2008. Effect of dietary starch or micro algae supplementation on rumen fermentation and milk fatty acid composition of dairy cows. J. Dairy Sci. 91, 4714-4727.

Burns, T.A., Kadegowda, A.K.G., Duckett, S.K., Pratt, S.L., Jenkins, T.C. 2012. Palmitoleic (16:1 cis-9) and cis-vaccenic (18:1 cis-11) acid alter lipogenesis in bovine adipocyte cultures. Lipids 47, 1143-1153.

Carreño, D., Hervás, G., Toral, P.G., Castro-Carrera, T., Frutos, P. 2016. Fish oil-induced milk fat depression and associated downregulation of mammary lipogenic genes in dairy ewes. J. Dairy Sci. 99, 7971-7981.

Castro-Carrera, T., Frutos, P., Leroux, C., Chilliard, Y., Hervás, G., Belenguer, A., Bernard, L., Toral, P.G. 2015. Dietary sunflower oil modulates milk fatty acid composition without major changes in adipose and mammary tissue fatty acid profile or related gene mRNA abundance in sheep. Animal 9, 582-591.

Conte, G., Dimauro, C., Serra, A., Macciotta, N.P.P., Mele, M. 2018. A canonical discriminant analysis to study the association between milk fatty acids of ruminal origin and milk fat depression in dairy cows. J. Dairy Sci. 101, 6497-6510.

Cruz-Hernandez, C., Kramer, J.K.G., Kennelly, J.J., Glimm, D.R., Sorensen, B.M., Okine, 
E.K., Goonewardene, L.A., Weselake, R.J. 2007. Evaluating the conjugated linoleic acid and trans 18:1 isomers in milk fat of dairy cows fed increasing amounts of sunflower oil and a constant level of fish oil. . J. Dairy Sci. 90, 3786-3801.

Dallaire, M.P., Taga, H., Ma, L., Corl, B.A., Gervais, R., Lebeuf, Y., Richard, F.J., Chouinard, P.Y. 2014. Effects of abomasal infusion of conjugated linoleic acids, Sterculia foetida oil, and fish oil on production performance and the extent of fatty acid $\Delta^{9}$-desaturation in dairy cows. J. Dairy Sci. 97, 6411-6425.

Dewanckele, L., Jing, L., Stefanska, B., Vlaeminck, B., Jeyanathan, J., Van Straalen, W.M., Koopmans, A., Fievez, V. 2019. Distinct blood and milk 18-carbon fatty acid proportions and buccal bacterial populations in dairy cows differing in reticulorumen $\mathrm{pH}$ response to dietary supplementation of rapidly fermentable carbohydrates. J. Dairy Sci. 102, 40254040.

Fougère, H., Delavaud, C., Bernard, L. 2018. Diets supplemented with starch and corn oil, marine algae, or hydrogenated palm oil differentially modulate milk fat secretion and composition in cows and goats: A comparative study. J. Dairy Sci. 101, 8429-8445.

Frutos, P., Toral, P.G., Belenguer, A., Hervás, G. 2018. Milk fat depression in dairy ewes fed fish oil: Might differences in rumen biohydrogenation, fermentation, or bacterial community explain the individual variation? J. Dairy Sci. 101, 6122-6132.

Frutos, P., Toral, P.G., Hervás, G. 2017. Individual variation of the extent of milk fat depression in dairy ewes fed fish oil: Milk fatty acid profile and mRNA abundance of candidate genes involved in mammary lipogenesis. J. Dairy Sci. 100, 9611-9622.

Gama, M.A.S., Garnsworthy, P.C., Griinari, J.M., Leme, P. R., Rodrigues, P.H.M., Souza, L.W.O., Lanna, D.P.D. 2008. Diet-induced milk fat depression: Association with changes in milk fatty acid composition and fluidity of milk fat. Livest. Sci. 115, 319-331.

Gervais, R., Chouinard, P.Y. 2008. Effects of intravenous infusion of conjugated diene 18:3 
isomers on milk fat synthesis in lactating dairy cows. J. Dairy Sci. 91, 3568-3578.

Gervais, R., McFadden, J.W., Lengi, A.J., Corl, B.A., Chouinard, P.Y. 2009. Effects of intravenous infusion of trans-10, cis-12 18: 2 on mammary lipid metabolism in lactating dairy cows. J. Dairy Sci. 92, 5167-5177.

Glasser, F., Doreau, M., Ferlay, A., Chilliard, Y. Technical note: Estimation of milk fatty acid yield from milk fat data. J. Dairy Sci. 90, 2302-2304.

Gómez-Cortés, P., de la Fuente, M.A., Toral, P.G., Frutos, P., Juárez, M., Hervás, G. 2011a. Effects of different forage:concentrate ratios in dairy ewe diets supplemented with sunflower oil on animal performance and milk fatty acid profile. J. Dairy Sci. 94, 45784588.

Gómez-Cortés, P., Frutos, P., Mantecón, A.R., Juárez, M., de la Fuente, M.A., Hervás, G. 2008a. Milk production, conjugated linoleic acid content, and in vitro ruminal fermentation in response to high levels of soybean oil in dairy ewe diet. J. Dairy Sci. 91, $1560-1569$

Gómez-Cortés, P., Frutos, P., Mantecón, A.R., Juárez, M., de la Fuente, M.A., Hervás, G. 2008b. Addition of olive oil to dairy ewe diets: Effect on milk fatty acid profile and animal performance. J. Dairy Sci. 91, 3119-3127.

Gómez-Cortés, P., Toral, P.G., Frutos, P., Juárez, M., de la Fuente, M.A., Hervás, G. 2011b. Effect of the supplementation of dairy sheep diet with incremental amounts of sunflower oil on animal performance and milk fatty acid profile. Food Chem. 125, 644-651.

Haenlein, G.F.W. 2007. About the evolution of goat and sheep milk production. Small Rumin. Res. 68, 3-6.

Harvatine, K.J., Boisclair, Y.R., Bauman, D.E. 2009. Recent advances in the regulation of milk fat synthesis. Animal 3, 40-54.

Hervás, G., Luna, P., Mantecón, A.R., Castañares, N., de la Fuente, M.A., Juárez, M., Frutos, 
P. 2008. Effect of diet supplementation with sunflower oil on milk production, fatty acid profile and ruminal fermentation in lactating dairy ewes. J. Dairy Res. 75, 399-405.

Hussein, M., Harvatine, K.H., Weerasinghe, W.M.P.B., Sinclair, L.A., Bauman, D.E. 2013. Conjugated linoleic acid-induced milk fat depression in lactating ewes is accompanied by reduced expression of mammary genes involved in lipid synthesis. J. Dairy Sci. 96, 382534.

INRA. 2007. Alimentation des bovins, ovins et caprins. Besoins des Animaux: Valeur des aliments. Tables INRA 2007. INRA, Versailles, France.

Kadegowda, A.K.G., Bionaz, M., Piperova, L.S., Erdman, R.A., Loor, J.J. 2009. Peroxisome proliferator-activated receptor-gamma activation and long-chain fatty acids alter lipogenic gene networks in bovine mammary epithelial cells to various extents. J. Dairy Sci. 92, 4276-4289.

Kairenius, P., Ärölä, A., Leskinen, H., Toivonen, V., Ahvenjärvi, S., Vanhatalo, A., Huhtanen, P., Hurme, T., Griinari, J.M., Shingfield, K.J. 2015. Dietary fish oil supplements depress milk fat yield and alter milk fatty acid composition in lactating cows fed grass silage based diets. J. Dairy Sci. 98, 5653-5672.

Keady, T.W.J., Mayne, C.S., Fitzpatrick, D.A. 2000. Effects of supplementation of dairy cattle with fish oil on silage intake, milk yield and milk composition. J. Dairy Res. 67, 137-153.

Kliem, K.E., Shingfield, K.J. 2016. Manipulation of milk fatty acid composition in lactating cows: Opportunities and challenges. Eur. J. Lipid Sci. Technol. 118, 1661-1683.

Leduc, M., Létourneau-Montminy, M.P., Gervais, R., Chouinard, P.Y. 2017. Effect of dietary flax seed and oil on milk yield, gross composition, and fatty acid profile in dairy cows: A meta-analysis and meta-regression. J. Dairy Sci. 100, 8906-8927.

Lock, A.L., Teles, B.M., Perfield, J.W., Bauman, D.E., Sinclair, L.A. 2006. A conjugated linoleic acid supplement containing trans-10, cis-12 reduces milk fat synthesis in lactating 
sheep. J. Dairy Sci. 89, 1525-1532.

Loor, J.J., Doreau, M., Chardigny, J.M., Ollier, A., Sebedio, J.L., Chilliard, Y. 2005a. Effects of ruminal or duodenal supply of fish oil on milk fat secretion and profiles of trans-fatty acids and conjugated linoleic acid isomers in dairy cows fed maize silage. Anim. Feed Sci. Technol. 119, 227-246.

Loor, J.J., Ferlay, A., Ollier, A., Chilliard, Y. 2005b. Relationship among trans and conjugated fatty acids and bovine milk fat yield due to dietary concentrate and linseed oil. Journal of Dairy Science 88, 726-740.

Mele, M., Buccioni, A., Petacchi, F., Serra, A., Banni, S., Antongiovanni, M., Secchiari, P. 2006. Effect of forage/concentrate ratio and soybean oil supplementation on milk yield, and composition from Sarda ewes. Anim. Res. 55, 273-285.

Moate, P.J., Chalupa, W., Boston, R.C., Lean, I.J. 2007. Milk fatty acids. I. Variation in the concentration of individual fatty acids in bovine milk. J. Dairy Sci. 90, 4730-4739.

Nudda, A., Correddu, F., Marzano, A., Battacone, G., Nicolussi, P., Bonelli, P., Pulina, G. 2015. Effects of diets containing grape seed, linseed, or both on milk production traits, liver and kidney activities, and immunity of lactating dairy ewes. J. Dairy Sci. 98, 1157-1166.

Oliveira, D.E., Gama, M.A.S., Fernandes, D., Tedeschi, L.O., Bauman, D.E. 2012. An unprotected conjugated linoleic acid supplement decreases milk production and secretion of milk components in grazing dairy ewes. J. Dairy Sci. 95, 1437-1446.

Palmquist, D.L., Jenkins, T.C. 2017. A 100-Year Review: Fat feeding of dairy cows. J. Dairy Sci. 100, 10061-10077.

Parente, M.O.M., Susin, I., Nolli, C.P., Ferreira, E.M., Gentil, R.S., Polizel, D.M., Pires, A.V., Alves, S.P., Bessa, R.J.B. 2018. Effects of supplementation with vegetable oils, including castor oil, on milk production of ewes and on growth of their lambs. J. Anim. Sci. 96, 354-363. 
Pirondini, M., Colombini, S., Mele, M., Malagutti, L., Rapetti, L., Galassi, G., Crovetto, G.M. 2015. Effect of dietary starch concentration and fish oil supplementation on milk yield and composition, diet digestibility, and methane emissions in lactating dairy cows. J. Dairy Sci. 98, 357-372.

Saliba, L., Gervais, R., Lebeuf, Y., Chouinard, P.Y. 2014. Effect of feeding linseed oil in diets differing in forage to concentrate ratio: 1. Production performance and milk fat content of biohydrogenation intermediates of $\alpha$-linolenic acid. J. Dairy Res. 81, 82-90.

Shi, H., Luo, J., Zhang, W., Sheng, H. 2015. Using safflower supplementation to improve the fatty acid profile in milk of dairy goat. Small Rumin. Res. 127, 68-73.

Shingfield, K.J., Bernard, L., Leroux, C., Chilliard, Y. 2010. Role of trans fatty acids in the nutritional regulation of mammary lipogenesis in ruminants. Animal 4, 1140-1166.

Shingfield, K.J., Sæbø, A., Sæbø, P.-C., Toivonen, V., Griinari, J.M. 2009. Effect of abomasal infusions of a mixture of octadecenoic acids on milk fat synthesis in lactating cows. J. Dairy Sci. 92, 4317-4329.

Sauvant, D., Schmidely, P., Daudin, J.J., St-Pierre, N.R. 2008. Meta-analyses of experimental data in animal nutrition. Animal 2, 1203-1214.

St-Pierre, N.R. 2003. Reassessment of biases in predicted nitrogen flows to the duodenum by NRC 2001. J. Dairy Sci. 86, 344-350.

Toral, P.G., Frutos, P., Hervás, G., Gómez-Cortés, P., Juárez, M., de la Fuente, M.A. 2010a. Changes in milk fatty acid profile and animal performance in response to fish oil supplementation, alone or in combination with sunflower oil, in dairy ewes. J. Dairy Sci. 93, 1604-1615.

Toral, P.G., Hervás, G., Belenguer, A., Carreño, D., Frutos, P. 2017. mRNA abundance of genes involved in mammary lipogenesis during fish oil- or trans-10,cis-12 CLA-induced milk fat depression in dairy ewes. J. Dairy Sci. 100, 3182-3192. 
Toral, P.G., Hervás, G., Belenguer, A., Bichi, E., Frutos, P. 2013. Effect of the inclusion of quebracho tannins in a diet rich in linoleic acid on milk fatty acid composition in dairy ewes. J. Dairy Sci. 96, 431-439.

Toral, P.G., Hervás, G., Bichi, E., Belenguer, A., Frutos, P. 2011. Tannins as feed additives to modulate ruminal biohydrogenation: Effects on animal performance, milk fatty acid composition and ruminal fermentation in dairy ewes fed a diet containing sunflower oil Anim. Feed Sci. Technol. 164, 199-206.

Toral, P.G., Hervás, G., Carreño, D., Belenguer, A., Frutos, P. 2015. Comparison of milk fatty acid responses during fish oil- and trans-10 cis-12 18:2-induced milk fat depression in dairy ewes. Anim. Feed Sci. Technol. 210, 66-73.

Toral, P.G., Hervás, G., Carreño, D., Frutos, P. 2016. Does supplemental 18:0 alleviate fish oilinduced milk fat depression in dairy ewes? J. Dairy Sci. 99, 1133-1144.

Toral, P.G., Hervás, G., Frutos, P. 2018. Use of high doses of 18:0 to try to mitigate the syndrome of milk fat depression in dairy ewes fed marine lipids Anim. Feed Sci. Technol. $236,68-75$.

Toral, P.G., Hervás, G., Frutos, P. 2019. In vitro biohydrogenation of ${ }^{13}$ C-labeled $\alpha$-linolenic acid in response to ruminal alterations associated with diet-induced milk fat depression in ewes. J. Dairy Sci. 102, 1213-1223.

Toral, P.G., Hervás, G., Gómez-Cortés, P., Frutos, P., Juárez, M., de la Fuente, M.A. 2010b. Milk fatty acid profile and dairy sheep performance in response to diet supplementation with sunflower oil plus incremental levels of marine algae. J. Dairy Sci. 93, 1655-1667.

Tsiplakou, E., Yiasoumis, L., Maragou, A.C., Mavrommatis, A., Sotirakoglou, K., Moatsou, G., Zervas, G. 2017. The response of goats to different starch/NDF ratios of concentrates on the milk chemical composition, fatty acid profile, casein fractions and rennet clotting properties. Small Rumin. Res. 156, 82-88. 
Urrutia, N., Harvatine, K.J. 2017. Effect of conjugated linoleic acid and acetate on milk fat synthesis and adipose lipogenesis in lactating dairy cows. J. Dairy Sci. 100, 5792-5804.

Vahmani, P., Fredeen, A.H., Glover, K.E. 2013. Effect of supplementation with fish oil or microalgae on fatty acid composition of milk from cows managed in confinement or pasture systems. J. Dairy Sci. 96, 6660-6670.

Vazirigohar, M., Dehghan-Banadaky, M., Rezayazdi, K., Krizsan, S.J., Nejati-Javaremi, A., Shingfield, K.J. 2014. Fat source and dietary forage-to-concentrate ratio influences milk fatty-acid composition in lactating cows. Animal 8, 163-174.

Zhang, R.H., Mustafa, A.F., Zhao, X. 2006. Effects of feeding oilseeds rich in linoleic and linolenic fatty acids to lactating ewes on cheese yield and on fatty acid composition of milk and cheese. Anim. Feed Sci. Technol. 127, 220-233. 
Table 1

Studies, experimental treatments, and number of lots per experimental treatment included in the meta-analysis.

\begin{tabular}{|c|c|c|c|c|c|c|c|c|}
\hline \multirow[b]{3}{*}{ Study } & \multirow[b]{3}{*}{$\mathrm{F}: \mathrm{C}^{1}$} & \multicolumn{3}{|c|}{ non-MFD ${ }^{2}$} & \multicolumn{3}{|c|}{$\mathrm{MFD}^{2}$} & \multirow{3}{*}{$\begin{array}{l}\text { Number of } \\
\text { ewes per lot }\end{array}$} \\
\hline & & \multirow{2}{*}{$\begin{array}{c}\text { Control } \\
\text { Lots }\end{array}$} & \multicolumn{2}{|r|}{ Treatment } & \multirow{2}{*}{$\begin{array}{c}\text { Control } \\
\text { Lots }\end{array}$} & \multicolumn{2}{|r|}{ Treatment } & \\
\hline & & & Lots & Supplement ${ }^{3}$ & & Lots & Supplement ${ }^{4}$ & \\
\hline Gómez-Cortés et al. (2008a) & $20: 80$ & 2 & 2 & Soybean oil (60) & - & - & - & 6 \\
\hline Gómez-Cortés et al. (2008b) & $20: 80$ & 2 & 2 & Olive oil (60) & - & - & - & 6 \\
\hline Hervás et al. (2008) & $20: 80$ & 2 & 2 & Sunflower oil (60) & - & - & - & 6 \\
\hline \multirow[t]{2}{*}{ Toral et al. (2010a) } & $21: 79$ & 2 & 2 & Sunflower oil (23) & 2 & 2 & Fish oil (11) & 8 \\
\hline & & & & & & 2 & $\begin{array}{l}\text { Fish oil (11) and } \\
\text { sunflower oil (23) }\end{array}$ & 8 \\
\hline \multirow[t]{3}{*}{ Toral et al. (2010b) } & $50: 50$ & 2 & 2 & Sunflower oil (25) & 2 & 2 & $\begin{array}{l}\text { Marine algae (8) and } \\
\text { sunflower oil (25) }\end{array}$ & 5 \\
\hline & & & & & & 2 & $\begin{array}{l}\text { Marine algae (16) and } \\
\text { sunflower oil (25) }\end{array}$ & 5 \\
\hline & & & & & & 2 & $\begin{array}{l}\text { Marine algae (14) and } \\
\text { sunflower oil (25) }\end{array}$ & 5 \\
\hline \multirow[t]{3}{*}{ Gómez-Cortés et al. (2011a) } & $71: 29$ & 2 & 2 & Sunflower oil (17) & - & - & - & 5 \\
\hline & $54: 46$ & 2 & 2 & Sunflower oil (34) & - & - & - & 5 \\
\hline & $31: 69$ & 2 & 2 & Sunflower oil (51) & - & - & - & 5 \\
\hline \multirow[t]{3}{*}{ Gómez-Cortés et al. (2011b) } & $21: 79$ & 2 & 2 & Sunflower oil (24) & - & - & - & 10 \\
\hline & & & 2 & Sunflower oil (24) & - & - & - & 10 \\
\hline & & & 2 & Sunflower oil (24) & - & - & - & 10 \\
\hline Toral et al. $(2011)^{5}$ & $40: 60$ & 1 & 1 & Tannin extract (10) & - & - & - & 7 \\
\hline Bichi et al. $(2013)^{6}$ & $40: 60$ & - & - & - & 3 & 3 & Marine algae (8) & 6 \\
\hline
\end{tabular}


Toral et al. $(2013)^{5}$

Castro-Carrera et al. (2015)

Toral et al. (2015)

Carreño et al. (2016)

Toral et al. (2016)

Frutos et al. (2017)

Toral et al. (2017)

Toral et al. (2018)

$\begin{array}{ll}40: 60 & 3 \\ 61: 39 & 1 \\ 40: 60 & - \\ 51: 49 & - \\ 41: 59 & -\end{array}$

\section{Tannin extract (20) \\ Sunflower oil (25)}

51:49

-
-

$-$

41:59

41:59

$\begin{array}{ll}- & - \\ - & - \\ - & -\end{array}$

-
-
1
1
3
3
2
1
1
1

$\begin{array}{cc}- & 6 \\ - & 5 \\ \text { Fish oil (20) } & 4 \\ \text { Fish oil (17) } & 6 \\ \text { Fish oil (20) } & 4 \\ \text { Fish oil (20) and } & 4 \\ \text { stearic acid (10) } & \\ \text { Fish oil (20) } & 5 \\ \text { Fish oil (24) } & 4 \\ \text { Fish oil (20) } & 4 \\ \text { Fish oil (20) and } & 4 \\ \text { stearic acid (30) } & \\ \text { Fish oil (20) and } \\ \text { stearic acid (40) }\end{array}$

\section{Sum of lot observations}

23

27

15

27

${ }^{1}$ Forage:concentrate ratio (DM basis) in the basal diet. The forage was dehydrated alfalfa hay in all the studies.

${ }^{2}$ Dietary conditions associated or not-associated with milk fat depression (MFD and non-MFD, respectively) in dairy ewes.

${ }^{3}$ Supplemented with plant oils (rich in cis-9 18:1, 18:2n-6 or 18:3n-3) or tannin extracts. The amount of each supplement (g/kg diet DM) is indicated in parentheses.

${ }^{4}$ Supplemented with marine lipids (rich in 20:5n-3 and 22:6n-3) or a mixture of marine lipids and plant oils (rich in 18:2n-6). The amount of each supplement $(\mathrm{g} / \mathrm{kg}$ diet $\mathrm{DM})$ is indicated in parentheses.

${ }^{5}$ The basal diet included $20 \mathrm{~g}$ of sunflower oil/kg DM.

${ }^{6}$ The basal diet included $25 \mathrm{~g}$ of sunflower oil/kg DM. 


\section{Table 2}

Diet composition, lactation performance traits and milk trans-10 shift indicators in dietary conditions associated or not-associated with milk fat depression (MFD and non-MFD, respectively) in dairy ewes.

\begin{tabular}{|c|c|c|c|c|c|c|c|c|c|}
\hline & \multicolumn{2}{|c|}{ non-MFD } & \multicolumn{2}{|c|}{ MFD } & \multirow[b]{2}{*}{$\mathrm{SED}^{3}$} & \multirow[b]{2}{*}{ P-value ${ }^{4}$} & \multicolumn{3}{|c|}{ Contrast $^{5}$} \\
\hline & Control & Treatment $^{1}$ & Control & Treatment $^{2}$ & & & $\begin{array}{l}\text { Control vs. } \\
\text { supplemented } \\
\text { (non-MFD) }\end{array}$ & $\begin{array}{l}\text { Control vs. } \\
\text { supplemented } \\
\text { (MFD) }\end{array}$ & $\begin{array}{l}\text { non-MFD } \\
\text { vs. MFD }\end{array}$ \\
\hline \multicolumn{10}{|l|}{ Diet composition, g/kg DM } \\
\hline Forage & 347 & 335 & 419 & 407 & 64.4 & 0.628 & & & \\
\hline Concentrate & 653 & 626 & 581 & 562 & 62.3 & 0.485 & & & \\
\hline Supplement ${ }^{6}$ & - & 38.8 & - & 31.2 & 6.92 & 0.292 & & & \\
\hline Organic matter & 892 & 893 & 902 & 900 & 4.9 & 0.212 & & & \\
\hline Crude protein & 172 & 168 & 183 & 180 & 6.3 & 0.002 & 0.003 & 0.020 & 0.085 \\
\hline aNDF & 270 & 269 & 266 & 256 & 22.9 & 0.793 & & & \\
\hline $\mathrm{ADF}$ & 171 & 170 & 171 & 167 & 26.2 & 0.973 & & & \\
\hline Total starch & 206 & 200 & 182 & 178 & 18.1 & 0.480 & & & \\
\hline Starch from corn grain & 131 & 127 & 113 & 111 & 14.1 & 0.531 & & & \\
\hline Starch from barley grain & 76.2 & 74.0 & 68.4 & 68.1 & 7.73 & 0.729 & & & \\
\hline Total fatty acids (FA) & 23.2 & 54.7 & 29.3 & 50.6 & 6.97 & $<0.001$ & $<0.001$ & 0.002 & 0.840 \\
\hline Total FA from plant lipids & 23.5 & 55.0 & 28.0 & 35.5 & 7.01 & $<0.001$ & $<0.001$ & 0.231 & 0.173 \\
\hline Total FA from marine lipids & - & - & - & 15.2 & - & & & & \\
\hline 14:0 & 0.16 & 0.16 & 0.28 & 0.91 & 0.098 & $<0.001$ & 0.971 & $<0.001$ & $<0.001$ \\
\hline 16:0 & 3.80 & 6.34 & 4.73 & 7.74 & 0.742 & $<0.001$ & $<0.001$ & $<0.001$ & 0.060 \\
\hline cis-9 16:1 & 0.06 & 0.09 & 0.10 & 0.65 & 0. in 127 & $<0.001$ & 0.818 & $<0.001$ & 0.010 \\
\hline
\end{tabular}




\begin{tabular}{|c|c|c|c|c|c|c|c|c|c|}
\hline 18:0 & 0.80 & 2.07 & 1.14 & 7.57 & 3.028 & 0.057 & 0.624 & 0.023 & 0.201 \\
\hline cis-9 18:1 & 5.81 & 18.73 & 5.33 & 7.84 & 3.28 & $<0.001$ & $<0.001$ & 0.369 & 0.041 \\
\hline cis-11 18:1 & 0.24 & 0.40 & 0.30 & 0.71 & 0.091 & $<0.001$ & 0.066 & $<0.001$ & 0.015 \\
\hline $18: 3 n-3$ & 1.26 & 1.47 & 2.20 & 2.32 & 0.437 & 0.114 & & & \\
\hline $20: 5 n-3$ & - & - & - & 0.86 & - & & & & \\
\hline \multicolumn{10}{|l|}{ Milk trans-10 shift indicators } \\
\hline trans-10,cis-12 CLA, g/kg total FA & 0.123 & 0.315 & 0.151 & 0.280 & 0.126 & $<0.001$ & $<0.001$ & 0.017 & 0.977 \\
\hline trans-10 18:1, g/kg total FA & 8.07 & 30.46 & 4.97 & 45.90 & 7.952 & $<0.001$ & $<0.001$ & $<0.001$ & 0.385 \\
\hline trans-10:trans-11 18:1 ratio & 0.429 & 0.865 & 0.409 & 0.953 & 0.282 & 0.002 & 0.006 & 0.003 & 0.893 \\
\hline $\mathrm{FPCM}^{7}$ & 1732 & 1859 & 2144 & 1869 & 188.8 & $<0.001$ & 0.030 & $<0.001$ & 0.263 \\
\hline Milk fat & 106 & 113 & 133 & 106 & 11.1 & $<0.001$ & 0.069 & $<0.001$ & 0.377 \\
\hline Milk de novo $\mathrm{FA}^{8}$ & 33.5 & 27.2 & 44.2 & 32.2 & 4.39 & $<0.001$ & $<0.001$ & $<0.001$ & 0.075 \\
\hline Milk C16 FA ${ }^{9}$ & 25.7 & 23.2 & 33.1 & 25.0 & 2.86 & $<0.001$ & 0.012 & $<0.001$ & 0.110 \\
\hline Milk preformed $\mathrm{FA}^{10}$ & 30.7 & 45.7 & 35.7 & 31.7 & 3.24 & $<0.001$ & $<0.001$ & 0.016 & 0.151 \\
\hline \multicolumn{10}{|l|}{ Concentration, $\mathrm{g} / \mathrm{kg}$} \\
\hline Milk fat & 55.4 & 54.2 & 58.3 & 46.4 & 2.19 & $<0.001$ & 0.255 & $<0.001$ & 0.234 \\
\hline Milk de novo $\mathrm{FA}^{8}$ & 334 & 255 & 353 & 322 & 17.5 & $<0.001$ & $<0.001$ & 0.006 & 0.011 \\
\hline
\end{tabular}




\begin{tabular}{lcccccccc}
\hline Milk C16 FA & 258 & 220 & 265 & 254 & 6.7 & $<0.001$ & $<0.001$ & 0.009 \\
Milk preformed FA $^{10}$ & 312 & 434 & 290 & 323 & 22.9 & $<0.001$ & $<0.001$ & 0.003 \\
\hline
\end{tabular}

${ }^{1}$ Supplemented with plant oils (rich in cis-9 18:1, 18:2n-6 or 18:3n-3) or tannin extracts.

${ }^{2}$ Supplemented with marine lipids (rich in 20:5n-3 and 22:6n-3) or a mixture of marine lipids and plant oils (rich in 18:2n-6).

${ }^{3}$ Standard error of the difference.

${ }^{4}$ Probability of significant effects of experimental treatment.

${ }^{5}$ Probability of the orthogonal contrasts (when the effect of the experimental treatment was significant).

${ }^{6}$ Statistical analysis compared non-MFD treatment vs. MFD treatment, because their respective controls did not receive the supplements.

${ }^{7}$ Fat- and protein-corrected milk yield.

${ }^{8}$ Mammary de novo synthesized fatty acids (FA) were calculated as the sum of 6:0, 8:0, 10:0, 12:0, 14:0, cis-9 10:1, cis-9 12:1 and cis-9 14:1 and expressed as $\mathrm{g} / \mathrm{kg}$ total FA.

${ }^{9}$ Calculated as the sum of 16:0 and 16:1 isomers and expressed as $\mathrm{g} / \mathrm{kg}$ total FA.

${ }^{10}$ Preformed FA derived from mammary uptake were calculated as the sum of FA with 18 or more carbon atoms and expressed as $\mathrm{g} / \mathrm{kg}$ total FA. 


\section{Table 3}

Prediction model parameters (mean \pm standard error) of milk, milk fat and major milk fatty acid (FA) groups in relation to milk trans-10,cis-12 conjugated linoleic acid (CLA) in dietary conditions associated or not-associated with milk fat depression (MFD and non-MFD, respectively) in dairy ewes.

\begin{tabular}{|c|c|c|c|c|c|c|c|c|c|c|c|c|c|}
\hline & \multicolumn{2}{|c|}{ Intercept $^{1}$} & \multicolumn{2}{|c|}{ Linear $t 10 c 12$ coefficient $^{2}$} & \multicolumn{2}{|c|}{${\text { Quadratic } t 10 c 12 \text { coefficient }^{3}}$} & \multicolumn{5}{|c|}{ P-value ${ }^{4}$} & \multicolumn{2}{|c|}{ Fit statistics ${ }^{5}$} \\
\hline & non-MFD & MFD & non-MFD & MFD & non-MFD & MFD & $\mathrm{D}$ & $t 10 c 12_{\mathrm{L}}$ & $t 10 c 12_{\mathrm{Q}}$ & $\begin{array}{c}\mathrm{D} \times \\
t 10 c 12_{\mathrm{L}}\end{array}$ & $\begin{array}{c}\mathrm{D} \times \\
t 10 c 12_{\mathrm{Q}}\end{array}$ & RMSE & $R^{2}$ \\
\hline \multicolumn{14}{|l|}{ Yield, g/d } \\
\hline Milk & $2031 \pm 149.8$ & $2312 \pm 158.5$ & \multicolumn{2}{|c|}{0} & \multicolumn{2}{|c|}{0} & 0.215 & - & - & - & - & 208.3 & 0.84 \\
\hline FPCM $^{6}$ & $1803 \pm 148.8$ & $2183 \pm 162.0$ & $119 \pm 143.2$ & $-912 \pm 306.4$ & \multicolumn{2}{|c|}{0} & 0.102 & 0.021 & - & 0.003 & - & 189.5 & 0.80 \\
\hline Milk fat & $108.2 \pm 10.48$ & $142.3 \pm 11.39$ & $26.2 \pm 31.69$ & $-152.6 \pm 39.94$ & $-18.6 \pm 24.18$ & $65.7 \pm 31.19$ & 0.041 & 0.015 & 0.237 & $<0.001$ & 0.036 & 12.59 & 0.76 \\
\hline Milk de novo $\mathrm{FA}^{7}$ & $38.3 \pm 3.30$ & $46.6 \pm 3.36$ & \multicolumn{2}{|c|}{$-48.3 \pm 10.52$} & \multicolumn{2}{|c|}{$24.4 \pm 8.12$} & 0.160 & $<0.001$ & 0.004 & - & - & 5.57 & 0.75 \\
\hline Milk C16 FA ${ }^{8}$ & $27.9 \pm 2.48$ & $34.6 \pm 2.69$ & $-21.2 \pm 7.05$ & $-35.8 \pm 7.89$ & \multicolumn{2}{|c|}{$13.0 \pm 5.22$} & 0.078 & $<0.001$ & 0.015 & 0.018 & - & 3.51 & 0.73 \\
\hline Milk preformed $\mathrm{FA}^{9}$ & $30.3 \pm 2.94$ & $29.9 \pm 3.20$ & $56.0 \pm 11.51$ & $31.3 \pm 11.84$ & \multicolumn{2}{|c|}{$-27.8 \pm 8.57$} & 0.908 & $<0.001$ & 0.002 & 0.006 & - & 5.91 & 0.65 \\
\hline \multicolumn{14}{|l|}{ Concentration, $\mathrm{g} / \mathrm{kg}$} \\
\hline Milk fat & $56.3 \pm 1.81$ & $52.7 \pm 1.86$ & \multicolumn{2}{|c|}{$-7.28 \pm 2.816$} & & ) & 0.156 & 0.012 & - & - & - & 4.76 & 0.51 \\
\hline Milk de novo $\mathrm{FA}^{7}$ & $349 \pm 12.7$ & $369 \pm 13.6$ & $-323 \pm 58.1$ & $-228 \pm 56.9$ & & \pm 43.3 & 0.247 & $<0.001$ & 0.004 & 0.018 & - & 31.1 & 0.69 \\
\hline Milk C16 FA ${ }^{8}$ & $259 \pm 4.4$ & $278 \pm 4.6$ & \multicolumn{2}{|c|}{$-130 \pm 23.5$} & & \pm 18.9 & 0.003 & $<0.001$ & $<0.001$ & - & - & 15.1 & 0.56 \\
\hline Milk preformed $\mathrm{FA}^{9}$ & $294 \pm 15.9$ & $256 \pm 16.8$ & $481 \pm 74.8$ & $362 \pm 72.4$ & & \pm 55.8 & 0.083 & $<0.001$ & $<0.001$ & 0.018 & - & 40.6 & 0.72 \\
\hline
\end{tabular}

${ }^{1}$ Common intercept values for non-MFD and MFD indicate non-significant effects of dietary conditions (D).

${ }^{2}$ Common coefficient values for non-MFD and MFD indicate a significant $(\mathrm{P}<0.05)$ linear effect of milk trans-10,cis-12 CLA $\left(t 10 c 12_{\mathrm{L}}\right)$ concentration $(\mathrm{g} / \mathrm{kg}$ total fatty acids) in the absence of a significant $\mathrm{D} \times t 10 c 12_{\mathrm{L}}$ interaction. Zero values indicate non-significant effects of $t 10 c 12_{\mathrm{L}}$ and $\mathrm{D} \times t 10 c 12_{\mathrm{L}}$.

${ }^{3}$ Common coefficient values for non-MFD and MFD indicate a significant $(\mathrm{P}<0.05)$ quadratic effect of milk trans-10,cis-12 CLA $\left(t 10 c 12_{\mathrm{Q}}\right)$ concentration $\left(\mathrm{g} / \mathrm{kg}\right.$ total fatty acids) in the absence of a significant $\mathrm{D} \times t 10 c 12_{\mathrm{Q}}$ interaction. Zero values indicate non-significant effects of $t 10 c 12_{\mathrm{Q}}$ and $\mathrm{D} \times t 10 c 12_{\mathrm{Q}}$.

${ }^{4}$ Significance of dietary condition effect (D), significance of linear effect of trans-10,cis-12 CLA $\left(t 10 c 12_{\mathrm{L}}\right)$, significance of quadratic effect of trans-10, cis- 
$12 \operatorname{CLA}\left(t 10 c 12_{\mathrm{Q}}\right)$, significance of interaction between $\mathrm{D}$ and $t 10 c 12_{\mathrm{L}}\left(\mathrm{D} \times t 10 c 12_{\mathrm{L}}\right)$, and significance of interaction between $\mathrm{D}$ and $t 10 c 12_{\mathrm{Q}}\left(\mathrm{D} \times t 10 c 12_{\mathrm{Q}}\right)$.

${ }^{5}$ Fit statistics of the prediction model: root mean squared error (RMSE) and coefficient of determination $\left(R^{2}\right)$ for the linear relationships between studentized residuals of observed and predicted values.

${ }^{6}$ Fat- and protein-corrected milk yield.

${ }^{7}$ Mammary de novo synthesized FA were calculated as the sum of 6:0, 8:0, 10:0, 12:0, 14:0, cis-9 10:1, cis-9 12:1 and cis-9 14:1 and expressed as g/kg total FA.

${ }^{8}$ Calculated as the sum of 16:0 and 16:1 isomers and expressed as $\mathrm{g} / \mathrm{kg}$ total FA.

${ }^{9}$ Preformed FA derived from mammary uptake were calculated as the sum of FA with 18 or more carbon atoms and expressed as g/kg total FA. 


\section{Table 4}

Prediction model parameters (mean \pm standard error) of milk, milk fat and major milk fatty acid (FA) groups in relation to milk trans-10 18:1 in dietary conditions associated or not-associated with milk fat depression (MFD and non-MFD, respectively) in dairy ewes.

\begin{tabular}{|c|c|c|c|c|c|c|c|c|c|c|c|c|c|}
\hline & \multicolumn{2}{|c|}{ Intercept $^{1}$} & \multicolumn{2}{|c|}{ Linear $t 10$ coefficient $^{2}$} & \multicolumn{2}{|c|}{ Quadratic $t 10$ coefficient $^{3}$} & \multicolumn{5}{|c|}{ P-value ${ }^{4}$} & \multicolumn{2}{|c|}{ Fit statistics ${ }^{5}$} \\
\hline & non-MFD & MFD & non-MFD & MFD & non-MFD & MFD & $\mathrm{D}$ & $t 10_{\mathrm{L}}$ & $t 10_{\mathrm{Q}}$ & $\begin{array}{l}\mathrm{D} \times \\
t 10_{\mathrm{L}} \\
\end{array}$ & $\begin{array}{c}\mathrm{D} \times \\
t 10_{\mathrm{Q}} \\
\end{array}$ & RMSE & $R^{2}$ \\
\hline \multicolumn{14}{|l|}{ Yield, g/d } \\
\hline Milk & $1867 \pm 151.3$ & $2278 \pm 161.8$ & $13.0 \pm 3.38$ & $5.9 \pm 2.98$ & \multicolumn{2}{|c|}{$-0.092 \pm 0.0326$} & 0.075 & 0.002 & 0.006 & 0.001 & - & 188.0 & 0.87 \\
\hline FPCM $^{6}$ & $1759 \pm 129.8$ & $2156 \pm 139.1$ & $2.0 \pm 1.49$ & $-6.3 \pm 1.32$ & \multicolumn{2}{|c|}{0} & 0.051 & 0.036 & - & $<0.001$ & - & 175.1 & 0.83 \\
\hline Milk fat & $109.1 \pm 7.66$ & $133.0 \pm 8.24$ & $0.043 \pm 0.0972$ & $-0.576 \pm 0.0865$ & \multicolumn{2}{|c|}{0} & 0.047 & $<0.001$ & - & $<0.001$ & - & 11.48 & 0.80 \\
\hline Milk de novo $\mathrm{FA}^{7}$ & $34.7 \pm 2.71$ & $43.6 \pm 2.82$ & \multicolumn{2}{|c|}{$-0.23 \pm 0.026$} & \multicolumn{2}{|c|}{0} & 0.036 & $<0.001$ & - & - & - & 4.66 & 0.82 \\
\hline Milk C16 FA ${ }^{8}$ & $25.7 \pm 1.91$ & $33.1 \pm 2.06$ & $-0.066 \pm 0.0256$ & $-0.171 \pm 0.0227$ & \multicolumn{2}{|c|}{0} & 0.016 & $<0.001$ & 0.003 & - & - & 3.03 & 0.80 \\
\hline Milk preformed $\mathrm{FA}^{9}$ & $29.6 \pm 2.68$ & $35.0 \pm 2.99$ & $0.668 \pm 0.1200$ & $-0.077 \pm 0.1210$ & $-0.0042 \pm 0.00121$ & $0.0004 \pm 0.00141$ & 0.190 & $<0.001$ & 0.041 & $<0.001$ & 0.016 & 5.44 & 0.70 \\
\hline \multicolumn{14}{|l|}{ Concentration, $\mathrm{g} / \mathrm{kg}$ milk } \\
\hline Milk fat & $56.8 \pm 1.74$ & $59.8 \pm 1.92$ & $-0.11 \pm 0.069$ & $-0.45 \pm 0.069$ & $0.0002 \pm 0.00070$ & $0.0029 \pm 0.0081$ & 0.257 & $<0.001$ & 0.005 & $<0.001$ & 0.014 & 3.08 & 0.79 \\
\hline Milk de novo $\mathrm{FA}^{7}$ & $332 \pm 11.0$ & $362 \pm 12.3$ & $-2.00 \pm 0.223$ & $-0.93 \pm 0.201$ & \multicolumn{2}{|c|}{0} & 0.077 & $<0.001$ & - & $<0.001$ & - & 28.0 & 0.74 \\
\hline Milk C16 FA ${ }^{8}$ & $261 \pm 5.7$ & $268 \pm 6.5$ & $-1.72 \pm 0.267$ & $-0.45 \pm 0.269$ & $0.011 \pm 0.0027$ & $0.002 \pm 0.0031$ & 0.460 & $<0.001$ & 0.002 & 0.001 & 0.048 & 12.2 & 0.72 \\
\hline Milk preformed $\mathrm{FA}^{9}$ & $302 \pm 17.1$ & $283 \pm 19.1$ & $4.82 \pm 0.745$ & $0.71 \pm 0.750$ & $-0.021 \pm 0.0075$ & $0.004 \pm 0.0088$ & 0.463 & $<0.001$ & 0.154 & $<0.001$ & 0.033 & 33.8 & 0.80 \\
\hline
\end{tabular}

${ }^{1}$ Common intercept values for non-MFD and MFD indicate non-significant effects of dietary conditions (D).

${ }^{2}$ Common coefficient values for non-MFD and MFD indicate a significant $(\mathrm{P}<0.05)$ linear effect of milk trans-10 18:1 $\left(t 10_{\mathrm{L}}\right)$ concentration $(\mathrm{g} / \mathrm{kg}$ total fatty acids) in the absence of a significant $\mathrm{D} \times t 10_{\mathrm{L}}$ interaction.

${ }^{3}$ Common coefficient values for non-MFD and MFD indicate a significant $(\mathrm{P}<0.05)$ quadratic effect of milk trans-10 18:1 $\left(t 10_{\mathrm{Q}}\right)$ concentration $(\mathrm{g} / \mathrm{kg}$ total fatty acids) in the absence of a significant $\mathrm{D} \times t 10_{\mathrm{Q}}$ interaction. Zero values indicate non-significant effects of $t 10_{\mathrm{Q}}$ and $\mathrm{D} \times t 10_{\mathrm{Q}}$.

${ }^{4}$ Significance of dietary condition effect (D), significance of linear effect of trans-10 18:1 $\left(t 10_{\mathrm{L}}\right)$, significance of quadratic effect of trans-10 $18: 1\left(t 10_{\mathrm{Q}}\right)$, significance of interaction between $\mathrm{D}$ and $t 10_{\mathrm{L}}\left(\mathrm{D} \times t 10_{\mathrm{L}}\right)$, and significance of interaction between $\mathrm{D}$ and $t 10_{\mathrm{Q}}\left(\mathrm{D} \times t 10_{\mathrm{Q}}\right)$. 
${ }^{5}$ Fit statistics of the prediction model: root mean squared error (RMSE) and coefficient of determination $\left(R^{2}\right)$ for the linear relationships between studentized residuals of observed and predicted values.

${ }^{6}$ Fat- and protein-corrected milk yield.

${ }^{7}$ Mammary de novo synthesized FA were calculated as the sum of 6:0, 8:0, 10:0, 12:0, 14:0, cis-9 10:1, cis-9 12:1 and cis-9 14:1 and expressed as g/kg total FA.

${ }^{8}$ Calculated as the sum of 16:0 and 16:1 isomers and expressed as $\mathrm{g} / \mathrm{kg}$ total FA.

${ }^{9}$ Preformed FA derived from mammary uptake were calculated as the sum of FA with 18 or more carbon atoms and expressed as g/kg total FA. 


\section{Table 5}

Prediction model parameters (mean \pm standard error) of milk, milk fat and major milk fatty acid (FA) groups in relation to milk trans-10:trans-

11 18:1 ratio in dietary conditions associated or not-associated with milk fat depression (MFD and non-MFD, respectively) in dairy ewes.

\begin{tabular}{|c|c|c|c|c|c|c|c|c|c|c|c|c|c|}
\hline & \multicolumn{2}{|c|}{ Intercept $^{1}$} & \multicolumn{2}{|c|}{ Linear $t 10: t 11$ coefficient $^{2}$} & \multicolumn{2}{|c|}{ Quadratic $t 10: t 11$ coefficient $^{3}$} & \multicolumn{5}{|c|}{ P-value ${ }^{4}$} & \multicolumn{2}{|c|}{ Fit statistics ${ }^{5}$} \\
\hline & non-MFD & MFD & non-MFD & MFD & non-MFD & MFD & $\mathrm{D}$ & $t 10: t 11_{\mathrm{L}}$ & $t 10: t 11_{\mathrm{Q}}$ & $\begin{array}{c}\mathrm{D} \times \\
t 10: t 11_{\mathrm{L}}\end{array}$ & $\begin{array}{c}\mathrm{D} \times \\
t 10: t 11_{\mathrm{Q}}\end{array}$ & RMSE & $R^{2}$ \\
\hline \multicolumn{14}{|l|}{ Yield, g/d } \\
\hline Milk & $1959 \pm 153.9$ & $2233 \pm 163.0$ & \multicolumn{2}{|c|}{$109 \pm 43.3$} & \multicolumn{2}{|r|}{0} & 0.230 & 0.003 & - & - & - & 199.4 & 0.86 \\
\hline $\mathrm{FPCM}^{6}$ & $1752 \pm 135.5$ & $2075 \pm 148.3$ & $73 \pm 51.9$ & $-137 \pm 72.0$ & \multicolumn{2}{|r|}{0} & 0.124 & 0.466 & - & 0.020 & - & 193.6 & 0.80 \\
\hline Milk fat & $108.8 \pm 8.05$ & $127.6 \pm 8.93$ & $2.0 \pm 3.60$ & $-15.5 \pm 5.01$ & \multicolumn{2}{|r|}{0} & 0.134 & 0.032 & - & 0.006 & - & 13.59 & 0.72 \\
\hline Milk de novo $\mathrm{FA}^{7}$ & $33.0 \pm 2.94$ & $39.8 \pm 3.14$ & \multicolumn{2}{|c|}{$-4.11 \pm 1.32$} & \multicolumn{2}{|r|}{0} & 0.115 & 0.003 & - & - & - & 6.34 & 0.67 \\
\hline Milk C16 FA & $24.8 \pm 2.06$ & $32.1 \pm 2.30$ & $-0.59 \pm 0.976$ & $-5.40 \pm 1.36$ & & 0 & 0.028 & $<0.001$ & - & 0.005 & - & 3.71 & 0.71 \\
\hline Milk preformed $\mathrm{FA}^{9}$ & $39.0 \pm 2.14$ & $33.6 \pm 2.29$ & \multicolumn{2}{|c|}{0} & & 0 & 0.105 & - & - & - & - & 7.29 & 0.45 \\
\hline \multicolumn{14}{|l|}{ Concentration, $\mathrm{g} / \mathrm{kg}$ milk } \\
\hline Milk fat & $57.8 \pm 2.02$ & $61.7 \pm 2.51$ & $-6.53 \pm 3.44$ & $-20.9 \pm 4.45$ & $1.09 \pm 0.857$ & $5.22 \pm 1.68$ & 0.225 & $<0.001$ & 0.001 & 0.013 & 0.031 & 3.87 & 0.67 \\
\hline Milk de novo $\mathrm{FA}^{7}$ & $312 \pm 12.5$ & $355 \pm 13.6$ & \multicolumn{2}{|c|}{$-28.6 \pm 7.52$} & \multicolumn{2}{|r|}{0} & 0.020 & $<0.001$ & - & - & - & 39.0 & 0.50 \\
\hline Milk preformed $\mathrm{FA}^{9}$ & $349 \pm 17.6$ & $282 \pm 19.0$ & \multicolumn{2}{|c|}{$39.7 \pm 10.1$} & \multicolumn{2}{|r|}{0} & 0.012 & $<0.001$ & - & - & - & 51.7 & 0.54 \\
\hline
\end{tabular}

${ }^{1}$ Common intercept values for non-MFD and MFD indicate non-significant effects of dietary conditions (D).

${ }^{2}$ Common coefficient values for non-MFD and MFD indicate a significant $(\mathrm{P}<0.05)$ linear effect of milk trans-10:trans-11 18:1 ratio $\left(t 10: t 11_{\mathrm{L}}\right)$ in the absence of a significant $\mathrm{D} \times t 10: t 11_{\mathrm{L}}$ interaction. Zero values indicate non-significant effects of $t 10: t 11_{\mathrm{L}}$ and $\mathrm{D} \times t 10: t 11_{\mathrm{L}}$.

${ }^{3}$ Common coefficient values for non-MFD and MFD indicate a significant $(\mathrm{P}<0.05)$ quadratic effect of milk trans-10:trans-11 18:1 ratio $\left(t 10: t 11_{\mathrm{Q}}\right)$ in the absence of a significant $\mathrm{D} \times t 10: t 11_{\mathrm{Q}}$ interaction. Zero values indicate non-significant effects of $t 10: t 11_{\mathrm{Q}}$ and $\mathrm{D} \times t 10: t 11_{\mathrm{Q}}$.

${ }^{4}$ Significance of dietary condition effect (D), significance of linear effect of trans-10:trans-11 18:1 (t10:t11 $\mathrm{L}_{\mathrm{L}}$ ), significance of quadratic effect of trans10:trans-11 18:1 (t10:t1 $\left.1_{\mathrm{Q}}\right)$, significance of interaction between $\mathrm{D}$ and $t 10: t 11_{\mathrm{L}}\left(\mathrm{D} \times t 10: t 11_{\mathrm{L}}\right)$, and significance of interaction between $\mathrm{D}$ and $t 10: t 11_{\mathrm{Q}}(\mathrm{D} \times$ 
$\left.t 10: t 11_{\mathrm{Q}}\right)$.

${ }^{5}$ Fit statistics of the prediction model: root mean squared error (RMSE) and coefficient of determination $\left(R^{2}\right)$ for the linear relationships between studentized residuals of observed and predicted values.

${ }^{6}$ Fat- and protein-corrected milk yield.

${ }^{7}$ Mammary de novo synthesized FA were calculated as the sum of 6:0, 8:0, 10:0, 12:0, 14:0, cis-9 10:1, cis-9 12:1 and cis-9 14:1 and expressed as g/kg total FA.

${ }^{8}$ Calculated as the sum of 16:0 and 16:1 isomers and expressed as $\mathrm{g} / \mathrm{kg}$ total FA.

${ }^{9}$ Preformed FA derived from mammary uptake were calculated as the sum of FA with 18 or more carbon atoms and expressed as g/kg total FA. 


\section{Figure 1}

Observations and graphical representation of regression equations for milk fat concentration in relation to milk trans-10 shift indicators in dietary conditions associated or not-associated with milk fat depression (MFD and non-MFD, respectively) in dairy ewes. The non-MFD condition ( ) included diets supplemented with plant oils and extracts that modified milk fatty acid profile without causing the low fat-milk syndrome, and their respective control diets. The MFD condition (O) included diets supplemented with marine lipids that induced the low-fat milk syndrome, and their corresponding control diets. Each point represents a lot observation.

\section{Figure 2}

Observations and graphical representation of regression equations for other lactation performance traits in relation to milk trans-10 18:1 concentrations in dietary conditions associated or not-associated with milk fat depression (MFD and non-MFD, respectively) in dairy ewes. The non-MFD condition $(\bigcirc)$ included diets supplemented with plant oils and extracts that modified milk fatty acid profile without causing the low fat-milk syndrome, and their corresponding control diets. The MFD condition (O) included diets supplemented with marine lipids that induced the low-fat milk syndrome, and their respective control diets. Each point represents a lot observation. Mammary de novo-synthesized fatty acids (FA) were calculated as the sum of $6: 0,8: 0,10: 0,12: 0,14: 0$, cis-9 10:1, cis-9 12:1 and cis-9 14:1, whereas the sum of FA with 18 or more carbon atoms was used to calculate preformed FA derived from mammary uptake. Both FA groups are expressed as $\mathrm{g} / \mathrm{kg}$ total FA in milk. 


\section{FIGURE 1}
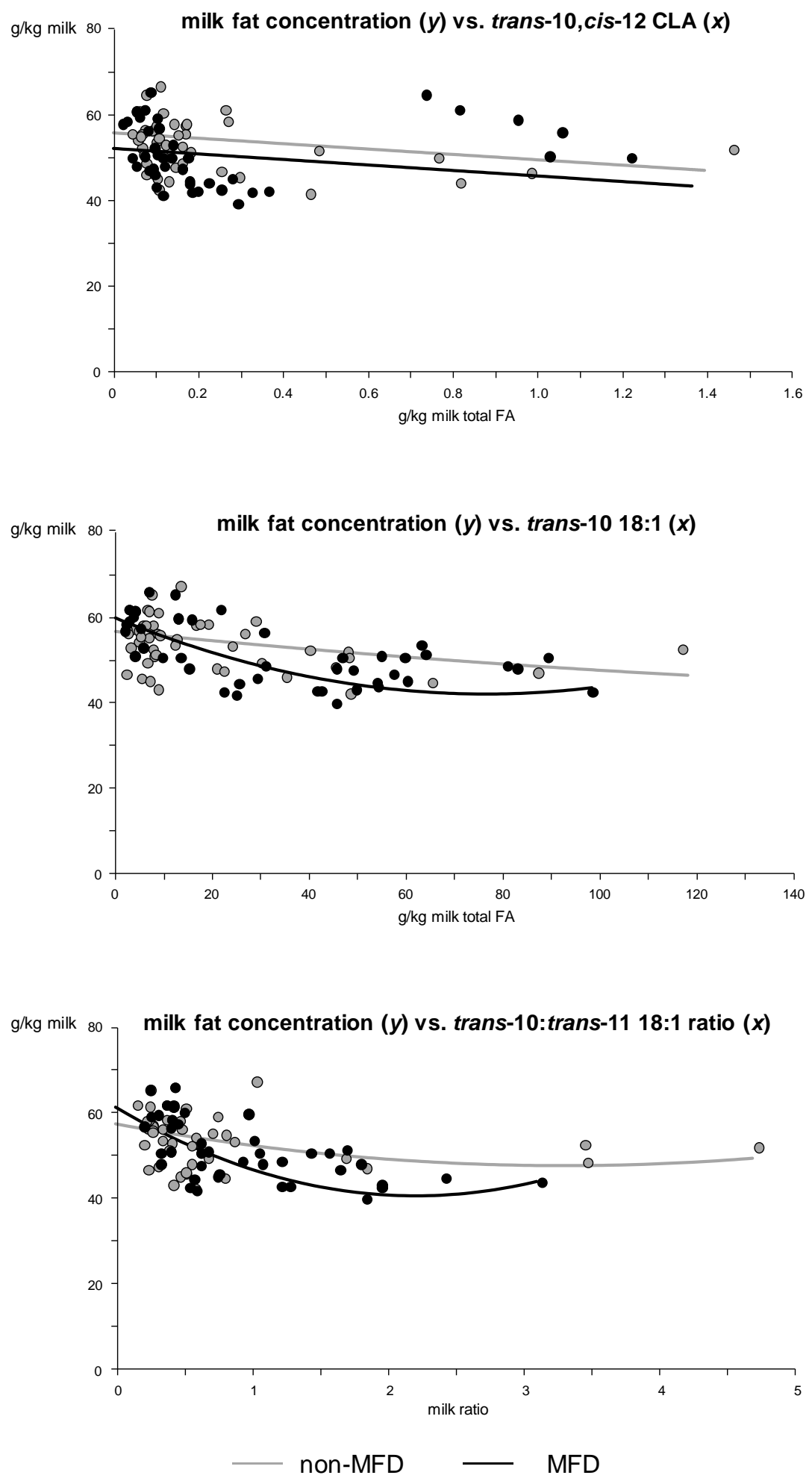


\section{FIGURE 2}
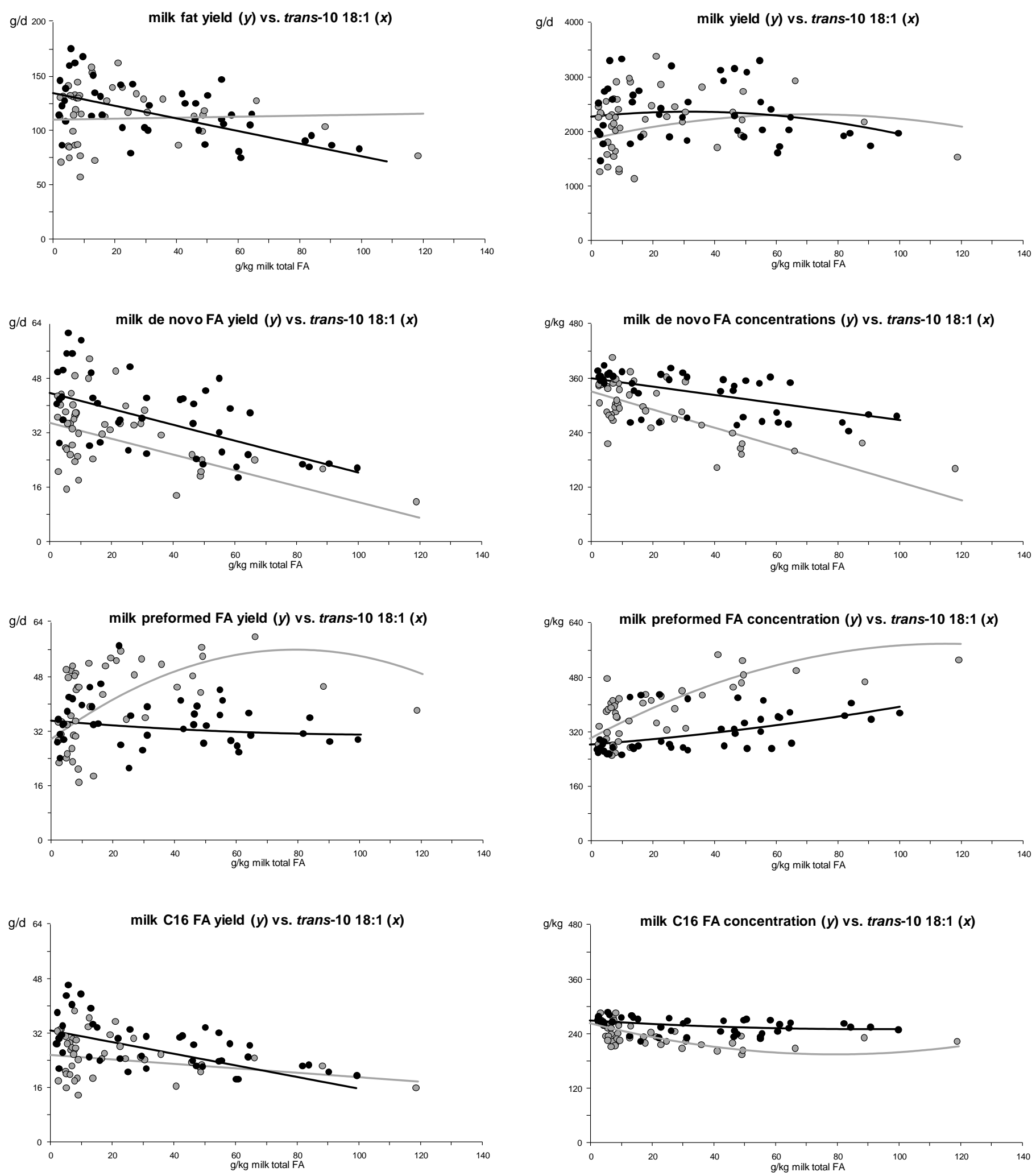


\section{Supplementary Table S1}

Pearson correlation coefficients ( $r$; P-values in brackets) among milk trans-10 shift indicators and lactation performance traits.

\begin{tabular}{|c|c|c|c|c|c|c|c|c|c|c|c|c|c|}
\hline & $\begin{array}{c}\text { trans }-10 \\
18: 1\end{array}$ & $\begin{array}{c}\text { trans-11 } \\
18: 1\end{array}$ & $\begin{array}{c}\text { trans-10: } \\
\text { trans-11 18:1 }\end{array}$ & $\begin{array}{l}\text { Milk } \\
\text { yield }\end{array}$ & $\mathrm{FPCM}^{1}$ & $\begin{array}{l}\text { Milk fat } \\
\text { yield }\end{array}$ & $\begin{array}{c}\text { Milk de } \\
\text { novo FA } \\
\text { yield }^{2} \\
\end{array}$ & $\begin{array}{l}\text { Milk C16 } \\
\text { FA yield }{ }^{3}\end{array}$ & $\begin{array}{c}\text { Milk } \\
\text { preformed } \\
\text { FA yield }^{4} \\
\end{array}$ & $\begin{array}{c}\text { Milk fat } \\
\text { concentration }\end{array}$ & $\begin{array}{c}\text { Milk } \\
\text { de novo FA } \\
\text { concentration }^{2}\end{array}$ & $\begin{array}{c}\text { Milk C16 } \\
\text { concentration }^{3}\end{array}$ & $\begin{array}{c}\text { Milk } \\
\text { preformed FA } \\
\text { concentration }^{4} \\
\end{array}$ \\
\hline $\begin{array}{l}\text { trans }-10 \\
\text { cis-12 CLA }\end{array}$ & $\begin{array}{c}0.465 \\
(<0.001)\end{array}$ & $\begin{array}{c}0.545 \\
(<0.001)\end{array}$ & $\begin{array}{c}0.158 \\
(0.137)\end{array}$ & $\begin{array}{l}-0.105 \\
(0.324)\end{array}$ & $\begin{array}{l}-0.159 \\
(0.135)\end{array}$ & $\begin{array}{l}-0.170 \\
(0.110)\end{array}$ & $\begin{array}{c}-0.407 \\
(<0.001)\end{array}$ & $\begin{array}{c}-0.446 \\
(<0.001)\end{array}$ & $\begin{array}{c}0.335 \\
(0.001)\end{array}$ & $\begin{array}{l}-0.089 \\
(0.404)\end{array}$ & $\begin{array}{c}-0.573 \\
(<0.001)\end{array}$ & $\begin{array}{l}-0.305 \\
(0.004)\end{array}$ & $\begin{array}{c}0.598 \\
(<0.001)\end{array}$ \\
\hline trans-10 18:1 & & $\begin{array}{c}0.587 \\
(<0.001)\end{array}$ & $\begin{array}{c}0.642 \\
(<0.001)\end{array}$ & $\begin{array}{l}-0.021 \\
(0.840)\end{array}$ & $\begin{array}{l}-0.195 \\
(0.063)\end{array}$ & $\begin{array}{c}-0.328 \\
(0.001)\end{array}$ & $\begin{array}{c}-0.472 \\
(<0.001)\end{array}$ & $\begin{array}{l}-0.245 \\
(0.019)\end{array}$ & $\begin{array}{c}0.064 \\
(0.547)\end{array}$ & $\begin{array}{c}-0.519 \\
(<0.001)\end{array}$ & $\begin{array}{c}-0.518 \\
(<0.001)\end{array}$ & $\begin{array}{c}-0.378 \\
(<0.001)\end{array}$ & $\begin{array}{c}0.434 \\
(<0.001)\end{array}$ \\
\hline trans-11 18:1 & & & $\begin{array}{l}-0.065 \\
(0.540)\end{array}$ & $\begin{array}{l}-0.043 \\
(0.681)\end{array}$ & $\begin{array}{l}-0.156 \\
(0.139)\end{array}$ & $\begin{array}{l}-0.215 \\
(0.039)\end{array}$ & $\begin{array}{c}-0.503 \\
(<0.001)\end{array}$ & $\begin{array}{c}-0.464 \\
(<0.001)\end{array}$ & $\begin{array}{c}0.360 \\
(<0.001)\end{array}$ & $\begin{array}{l}-0.301 \\
(0.004)\end{array}$ & $\begin{array}{c}-0.657 \\
(<0.001)\end{array}$ & $\begin{array}{c}-0.373 \\
(<0.001)\end{array}$ & $\begin{array}{c}0.620 \\
(<0.001)\end{array}$ \\
\hline $\begin{array}{l}\text { trans-10: } \\
\text { trans }-11 \text { 18:1 }\end{array}$ & & & & $\begin{array}{c}0.090 \\
(0.392)\end{array}$ & $\begin{array}{l}-0.030 \\
(0.775)\end{array}$ & $\begin{array}{l}-0.141 \\
(0.179)\end{array}$ & $\begin{array}{l}-0.180 \\
(0.086)\end{array}$ & $\begin{array}{l}-0.100 \\
(0.335)\end{array}$ & $\begin{array}{l}-0.014 \\
(0.891)\end{array}$ & $\begin{array}{c}-0.379 \\
(<0.001)\end{array}$ & $\begin{array}{l}-0.215 \\
(0.039)\end{array}$ & $\begin{array}{l}-0.151 \\
(0.151)\end{array}$ & $\begin{array}{c}0.173 \\
(0.099)\end{array}$ \\
\hline Milk yield & & & & & $\begin{array}{c}0.949 \\
(<0.001)\end{array}$ & $\begin{array}{c}0.841 \\
(<0.001)\end{array}$ & $\begin{array}{c}0.740 \\
(<0.001)\end{array}$ & $\begin{array}{c}0.063 \\
(0.549)\end{array}$ & $\begin{array}{c}0.464 \\
(<0.001)\end{array}$ & $\begin{array}{c}-0.356 \\
(<0.001)\end{array}$ & $\begin{array}{c}0.290 \\
(0.005)\end{array}$ & $\begin{array}{c}0.766 \\
(<0.001)\end{array}$ & $\begin{array}{c}-0.240 \\
(0.021)\end{array}$ \\
\hline FPCM $^{1}$ & & & & & & $\begin{array}{c}0.966 \\
(<0.001)\end{array}$ & $\begin{array}{c}0.854 \\
(<0.001)\end{array}$ & $\begin{array}{c}0.105 \\
(0.319)\end{array}$ & $\begin{array}{c}0.527 \\
(<0.001)\end{array}$ & $\begin{array}{l}-0.053 \\
(0.616)\end{array}$ & $\begin{array}{c}0.339 \\
(<0.001)\end{array}$ & $\begin{array}{c}0.895 \\
(<0.001)\end{array}$ & $\begin{array}{c}-0.278 \\
(0.007)\end{array}$ \\
\hline Milk fat yield & & & & & & & $\begin{array}{c}0.867 \\
(<0.001)\end{array}$ & $\begin{array}{c}0.095 \\
(0.370)\end{array}$ & $\begin{array}{c}0.578 \\
(<0.001)\end{array}$ & $\begin{array}{c}0.187 \\
(0.074)\end{array}$ & $\begin{array}{c}0.326 \\
(0.002)\end{array}$ & $\begin{array}{c}0.922 \\
(<0.001)\end{array}$ & $\begin{array}{l}-0.255 \\
(0.014)\end{array}$ \\
\hline $\begin{array}{l}\text { Milk de novo } \\
\text { FA yield }{ }^{2}\end{array}$ & & & & & & & & $\begin{array}{c}0.448 \\
(<0.001)\end{array}$ & $\begin{array}{c}0.114 \\
(0.278)\end{array}$ & $\begin{array}{c}0.147 \\
(0.162)\end{array}$ & $\begin{array}{c}0.742 \\
(<0.001)\end{array}$ & $\begin{array}{c}0.938 \\
(<0.001)\end{array}$ & $\begin{array}{c}-0.678 \\
(<0.001)\end{array}$ \\
\hline $\begin{array}{l}\text { Milk C16 } \\
\text { FA yield }\end{array}$ & & & & & & & & & $\begin{array}{l}-0.660 \\
(<0.001)\end{array}$ & $\begin{array}{c}0.036 \\
(0.736)\end{array}$ & $\begin{array}{c}0.695 \\
(<0.001)\end{array}$ & $\begin{array}{c}0.465 \\
(<0.001)\end{array}$ & $\begin{array}{c}-0.851 \\
(<0.001)\end{array}$ \\
\hline $\begin{array}{l}\text { Milk preformed } \\
\text { FA yield }{ }^{4}\end{array}$ & & & & & & & & & & $\begin{array}{c}0.148 \\
(0.158)\end{array}$ & $\begin{array}{c}-0.515 \\
(<0.001)\end{array}$ & $\begin{array}{c}0.258 \\
(0.013)\end{array}$ & $\begin{array}{c}0.625 \\
(<0.001)\end{array}$ \\
\hline $\begin{array}{l}\text { Milk fat } \\
\text { concentration }\end{array}$ & & & & & & & & & & & $\begin{array}{c}0.044 \\
(0.679)\end{array}$ & $\begin{array}{c}0.182 \\
(0.083)\end{array}$ & $\begin{array}{l}-0.008 \\
(0.943)\end{array}$ \\
\hline $\begin{array}{l}\text { Milk de novo } \\
\text { FA concentration }\end{array}$ & & & & & & & & & & & & $\begin{array}{c}0.540 \\
(<0.001)\end{array}$ & $\begin{array}{c}-0.954 \\
(<0.001)\end{array}$ \\
\hline $\begin{array}{l}\text { Milk C16 } \\
\text { FA concentration }{ }^{3}\end{array}$ & & & & & & & & & & & & & $\begin{array}{l}-0.541 \\
(<0.001)\end{array}$ \\
\hline
\end{tabular}

${ }^{1}$ Fat- and protein-corrected milk yield.

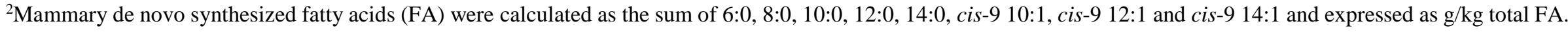
${ }^{3}$ Calculated as the sum of 16:0 and 16:1 isomers and expressed as $\mathrm{g} / \mathrm{kg}$ total FA.

${ }^{4}$ Preformed FA derived from mammary uptake were calculated as the sum of FA with 18 or more carbon atoms and expressed as g/kg total FA. 